\title{
GAS-PHASE REACTIVITY OF SILVER AND COPPER COORDINATED MONOSACCHARIDES CATIONS STUDIED BY ELECTROSPRAY IONIZATION AND TANDEM MASS SPECTROMETRY.
}

Laurence Boutreau $^{\dagger}$, Emmanuelle Léon $^{\mathrm{a}}$, Jean-Yves Salpin ${ }^{\mathrm{a}}$, Badia Amekraz ${ }^{\mathrm{b}}$, Christophe Moulin $^{\mathrm{b}}$ and Jeanine Tortajada ${ }^{\mathrm{a}^{*}}$.

a Laboratoire Analyse et Environnement, UMR CNRS 8587, Université d'Evry Val d’Essonne Bât. des Sciences, Boulevard François Mitterrand, 91025 EVRY CEDEX, France.

b CEA SACLAY, DEN/DPC/SECR, Laboratoire de Spéciation des radionucléides et des Molécules, Bâtiment 391, 91191 GIF/YVETTE CEDEX, France.

This work is dedicated to Pr. Robert Flammang on the occasion of his $60^{\text {th }}$ birthday

*Corresponding author. e-mail jeanine.tortajada@chimie.univ-evry.fr, FAX: (33) 169477655.

† Present adress: UCB Chemicals, Analytical Department, Anderlechtstraat, 33, B-1620 Drogenbos, Belgium. 


\section{ABSTRACT}

The analytical distinction of the most common isomeric underivatized hexoses was investigated by means of mass spectrometry experiments. Electrospray ionization and tandem mass spectrometry were used in the analysis of silver and copper-coordinated monosaccharides (D-glucose, D-galactose, D-fructose, O-methyl- $\alpha$-D-glucose and O-methyl$\beta$-D-glucose). The results show that cationization by $\mathrm{Ag}^{+}$allows to differentiate the three first monosaccharides while the complexes formed by association of $\mathrm{Cu}^{+}$with these three monosacharides display a similar reactivity that prevents stereoisomer distinction. Unlike copper, silver adduct-ions of both $\alpha$ and $\beta$ anomeric O-methyl-D-glucoses exhibit specific decomposition patterns, (i.e.: a loss of methanol for the $\alpha$-anomer and a loss of silver hydride for the $\beta$-anomer) which allow an easy characterization. A theoretical survey of selected complexes, based on the use of DFT calculations were carried out on both anomers in order to rationalize the experimental findings.

Keywords: mass spectrometry, gas phase, electrospray, cationization, silver, copper, monosaccharides, glucosides, DFT calculations 


\section{INTRODUCTION}

Carbohydrates are a class of vital compounds. In addition to their implication in numerous biological processes these molecules can also play an important role in environment because of their capacity to form very stable complexes with metal ions like humic and fulvic acids, which are decomposition products of cellulose. These compounds present a large number of possible linkage sites able to capture and transport metal cations in aqueous environment. Understanding such complicated mechanisms requires a progressive approach that consists first in the study of the intrinsic complexation properties of several monosaccharides toward metal cations. In this context complexation studies achieved by mass spectrometry associated with electrospray ionization can provide some insights into structures and reactivity of organometallic species that result from such interactions. In addition these studies can be useful to grasp in what extend, electrospray ionization (ESI) mass spectra reflect the organometallic chemistry in aqueous solution.

The reactivity between carbohydrates and metal ions has been widely studied in solution ${ }^{\mathbf{1 , 2}}$. In the last few years, several contributions have also reported the gas-phase mass spectrometric study of the complexation of glycosides by alkali, alkaline earth, metal chloride and transition metal cations. All these studies showed that gas-phase metal ion chemistry is a powerful tool in the stereochemical differentiation ${ }^{3-12}$ or linkage position determination ${ }^{13-16}$ of saccharides.

Theoretical approaches combined with experimental studies have been also carried out in order to have more reliable information about structure-reactivity relationship ${ }^{17-20}$.

Here we report an ESI-MS/MS study dealing with the gas-phase reactivity of two metal ions, namely $\mathrm{Ag}^{+}$and $\mathrm{Cu}^{+}$, with the three most common monosaccharides: D-glucose (1), Dgalactose (2), D-fructose (3), and the two anomers O-methyl- $\alpha$-D-glucose (4) and O-methyl$\beta$-D-glucose (5) presented in their pyranose form in scheme 1. 
$<$ Scheme 1>

One of the objectives of this work is to explore the analytical potential of metal ion cationization combined with electrospray ionization and MS/MS experiments, to differentiate monosaccharide stereoisomers and to distinguish anomers.

\section{EXPERIMENTAL SECTION}

The electrospray ionization (ESI) mass spectra were acquired on a Quattro II (Micromass, Manchester, UK.) triple quadrupole mass spectrometer. The solutions were infused, through a syringe pump at a flow rate of $10 \mu \mathrm{l} \cdot \mathrm{min}^{-1}$, into the electrospray source. Direct MS experiments were carried out at several cone voltages (5-300V). Nitrogen was used as nebulizing and drying gas, at a pressure of approximately of $3.0 \times 10^{5} \mathrm{~Pa}$. As usual for electrospray sources, the voltage applied on the extracting cone at the end of the transfer capillary may be varied to achieve some fragmentations (so called nozzle-skimmer collisioninduced decompositions). Our spectral data were averaged over a 60 seconds acquisition time. Direct ESI-MS/MS experiments were carried out by using argon as collision gas at several collision energy values $(0-30 \mathrm{eV})$, with an analyzer pressure of $\sim 2.0 \times 10^{-3} \mathrm{~Pa}$ and a gas cell pressure of $\sim 1.1 \times 10^{-1} \mathrm{~Pa}$.

The sample solutions were prepared by dissolving monosaccharides and metallic salts $\left(\mathrm{AgNO}_{3}\right.$ or $\left.\mathrm{CuCl}_{2}, 2 \mathrm{H}_{2} \mathrm{O}\right)$ in water. Because of $\mathrm{Cu}(\mathrm{I})$ salts are instable in ESI solution, $\mathrm{Cu}(\mathrm{II})$ salts have been used to generate $\mathrm{Cu}^{+}$complexes. The concentrations in each component are $10^{-5} \mathrm{~mol}^{-1} \mathrm{l}^{-1}$ (for monosaccharides) and $5 \times 10^{-6} \mathrm{~mol}^{-1}{ }^{-1}$ (for metallic salts).

Monosaccharides (D-glucose, D-galactose, D-fructose, O-methyl- $\alpha$-D-glucose and Omethyl- $\beta$-D-glucose) and metallic salts $\left(\mathrm{AgNO}_{3}\right.$ and $\left.\mathrm{CuCl}_{2}, 2 \mathrm{H}_{2} \mathrm{O}\right)$ were purchased from Aldrich Chemical Company and used without any further purification. 


\section{COMPUTATIONAL DETAILS}

Given the size of this system, an extensive study consisting of PM3 semiempirical calculations, ${ }^{21 a}$ starting from lowest energy structures of neutral D-Glucose (proposed by Jebber et al ${ }^{17 a}$ and Ma et al ${ }^{17 c}$ ) and replacing the anomeric $\mathrm{OH}$ group by $\mathrm{O}-\mathrm{CH}_{3}$, was carried out in a preliminary step. Further, from this survey, the two most stable structures for $\alpha$ and $\beta$ D-O-methyl glucopyranoside were reoptimized at the DFT level.

The number of conformational possibilities becomes very important when the interaction with $\mathrm{Ag}^{+}$and $\mathrm{Cu}^{+}$is considered. So, in this study we have restricted our survey on the possible structures which could account for the main experimental findings, especially for methanol and silver hydride eliminations from metal $\alpha$ and $\beta$-D-O-methyl glucopyranoside adduct ions. Like neutral species, for metal $\alpha$ and $\beta$-D-O-methyl glucopyranoside complexes, the most stable structures obtained at PM3 level were reoptimized at the DFT level.

Full geometry optimizations and harmonic vibrational frequency calculations of neutral and cationized species have been performed using the Becke's three-parameter non-local hybrid exchange potential. ${ }^{21 b}$ with the non-local correlation functional of Lee, Yang, Parr (B3LYP). ${ }^{21 c}$ This approach is known to yield reliable geometries for a wide variety of systems, including many transition metal containing systems. ${ }^{22-26}$

Geometry optimization has been carried out with the 6-311G(d,p) basis set for C, O, H and $\mathrm{Cu}$. For Ag we used the relativistic effective core potentials (RECP) developed by Hay and Wadt $^{27}$ (LANL2DZ). These RECP include the outermost core orbitals $4 \mathrm{~s}$ and $4 \mathrm{p}$ in the valence shell. The valence basis set is a [3s3p2d] contraction of a (5s6p4d) primitive set of Hay and Wadt ${ }^{27}$ supplemented with one set of $\mathrm{f}$ functions $\left(\alpha_{\mathrm{f}}=0.467\right)$. This basis set will 
hereby be denoted as Basis1. Harmonic vibrational frequencies of the different stationary points of the potential energy surface (PES) have been calculated at the same level of theory in order to identify the local minima as well as to estimate the corresponding zero point energies (ZPE).

Final energies have been obtained at the B3LYP level using the following basis. For C, O, $\mathrm{H}$ and $\mathrm{Cu}$ we use the 6-311G(2df,2p) basis set. For Ag we have used the (5s6p4d)/ [3s3p4d] basis set (by decontracting the $\mathrm{d}$ functions) supplemented with two sets of $\mathrm{f}$ functions $\left(\alpha_{\mathrm{f}}=0.946,0.237\right)$. Hereafter, this basis set will be referred to as Basis2.

The basis set superposition error (BSSE) has not been considered in the present study because for DFT methods this error is usually small using a flexible basis set expansion (e.g. $5-10 \mathrm{~kJ} \mathrm{~mol}^{-1}$ ), as has been previously reported. ${ }^{28}$. Moreover, because the corrections are likely to be comparable, BSSE can be neglected in the current study when relative energies are considered.

All calculations have been carried out by using Hyperchem ${ }^{29 a}$ and Gaussian 98 series of programs. $^{29 b}$

\section{RESULTS}

\section{Reactivity of D-glucose, D-galactose and D-fructose with $\mathbf{A g}^{+}$.}

In electrospray conditions, it is well known that the relative intensities of organometallic species in the ESI spectra are dependent on the cone voltage (increasing the voltage may cause CID in its vicinity where the pressure is close to atmospheric one). We have carried out some experiments at different cone voltage values (10 to $50 \mathrm{~V})$. It turns out that the value of 35V gives the more abundant adducts of interest, i.e. $\left[\mathrm{Ag}(\text { monosaccharide) }]^{+}\right.$.

The ESI-MS spectra of aqueous mixtures of D-glucose (1), D-galactose (2) and D-fructose (3) with silver nitrate are presented in Figure 1. 
$<$ Figure $1>$

Silver ions are seen in their natural abundance, i.e. $51 \%{ }^{107} \mathrm{Ag}$ and $49 \%{ }^{109} \mathrm{Ag}$. The existence of these two isotopes results in an easy identification of silver-containing ions. It is important to note that these spectra do not display protonated species but principally $\mathrm{Na}^{+}$and $\mathrm{Ag}^{+}$-monosaccharides complexes at m/z 203 and m/z 287/289 respectively. At a cone voltage of $35 \mathrm{~V}$, we can observe a weak doublet at $\mathrm{m} / \mathrm{z} 467 / 469$ corresponding to the interaction of both isotopes ${ }^{107} \mathrm{Ag}^{+}$and ${ }^{109} \mathrm{Ag}^{+}$with two monosaccharide units. As we can see in Figure 1, positive ion ESI/MS spectra do not allow the aldoses (D-glucose and D-galactose ) and the ketose (D-fructose ) to be differentiated, even though in the case of D-fructose an additional ion at $\mathrm{m} / \mathrm{z} 269 / 271$ is detected and which would correspond to [Ag(monosaccharide)- $\left.\mathrm{H}_{2} \mathrm{O}\right]^{+}$.

In ESI conditions it is assumed that the observed [Ag(monosaccharide) ${ }^{+}$complexes can result principally from the decompositions of highly coordinated precursor ions. Indeed, the presence and the behavior of silvered species depend on the cone voltage. It is worth noting that the cation $\mathrm{Ag}^{+}$is only observed at higher voltage. These features seem to indicate that [Ag-(monosaccharide) $]^{+}$, as well as $\mathrm{Ag}^{+}$cation, come from decomposition of species in which $\mathrm{Ag}^{+}$is multi-ligated.

The following section presents the MS/MS spectra of selected [Ag-(monosaccharide) ${ }^{+}$ complexes. The experiments performed on silvered species containing isotope ${ }^{107} \mathrm{Ag}$ and isotope ${ }^{109} \mathrm{Ag}$ lead to the same results. Thus, only MS/MS spectra containing $107 \mathrm{Ag}^{+}$will be presented.

The low-energy CID (ESI/MS/MS) spectra of the ${ }^{107} \mathrm{Ag}$ adduct ions of D-glucose, D-galactose, and D-fructose: $[\mathrm{Ag}(\text { glucose })]^{+},[\mathrm{Ag} \text { (galactose) }]^{+}$, and $[\mathrm{Ag}(\text { fructose })]^{+}$(at $\mathrm{m} / \mathrm{z}$ 287), recorded at a collision energy of $15 \mathrm{eV}$ (laboratory frame), are presented in Figure 2. 
As we can see, these spectra display a quite rich reactivity. Although the silvered aldoses $[\mathrm{Ag}(\text { glucose })]^{+}$and $[\mathrm{Ag}(\text { galactose })]^{+}$present the same fragmentations, differences in relative intensities permit to differentiate the two isomers.

So, starting from $[\mathrm{Ag}(\text { glucose })]^{+}$ion (m/z 287), we can observe, in addition to the formation of $\mathrm{Ag}^{+}$, the loss of one molecule of water (at m/z 269) and the losses of $60 \mathrm{u}, 90 \mathrm{u}$ and $120 \mathrm{u}$ (which can correspond to $\mathrm{C}_{2} \mathrm{H}_{4} \mathrm{O}_{2}, \mathrm{C}_{3} \mathrm{H}_{6} \mathrm{O}_{3}$ and $\mathrm{C}_{4} \mathrm{H}_{8} \mathrm{O}_{4}$ molecules leading to 227, 197, 167 ions, as we will see later). From the $\mathrm{m} / \mathrm{z} 227$ ion, consecutive $\mathrm{C}_{2} \mathrm{H}_{4} \mathrm{O}_{2}$ and $\mathrm{H}_{2} \mathrm{O}$ eliminations (at m/z 209 and m/z 191) occur.

In the case of $[\mathrm{Ag} \text { (galactose) }]^{+}$ion, aside the reverse reaction leading to $\mathrm{Ag}^{+}$, the principal fragmentation pathway corresponds to the loss of $90 \mathrm{u}\left(\mathrm{C}_{3} \mathrm{H}_{6} \mathrm{O}_{3}\right)$ leading to ion at $\mathrm{m} / \mathrm{z} 197$. The loss of water at m/z 269 is also accompanied by the elimination of $60 \mathrm{u}\left(\mathrm{C}_{2} \mathrm{H}_{4} \mathrm{O}_{2}\right)$.

Finally, the major reaction of the $[\mathrm{Ag}(\text { fructose })]^{+}$, corresponds to a dehydration process. In this complex, the loss of $90 \mathrm{u}\left(\mathrm{C}_{3} \mathrm{H}_{6} \mathrm{O}_{3}\right)$ at $\mathrm{m} / \mathrm{z} 197$ is also important. On the basis of the fragmentation pathways of $[\mathrm{Ag}(\text { glucose })]^{+},[\mathrm{Ag}(\text { galactose })]^{+}$, and $[\mathrm{Ag}(\text { fructose })]^{+}$complexes, we can see that the activation induced by silver cationization allow the three isomers to be differentiated. Such a differentiation has been also previously reported for $[\text { Ag(glucose) }]^{+}$, $[\mathrm{Ag}(\text { galactose })]^{+}$, and $[\mathrm{Ag}(\text { fructose })]^{+}$generated by FAB.$^{\mathbf{1 0}}$ These differences of reactivity will be discussed later.

\section{Reactivity of O-methyl- $\alpha$-D-glucoside and O-methyl- $\beta$-D-glucoside with $\mathrm{Ag}^{+}$.}

In the same way, ESI spectra of silvered O-methyl- $\alpha$-D-glucose and O-methyl- $\beta$-Dglucose complexes ( $\boldsymbol{\alpha}-\mathbf{4}$ and $\boldsymbol{\beta}-\mathbf{5})$ are similar and display the same trends, i.e., formation of $\mathrm{Ag}^{+}$-double adducts that lead to $[\mathrm{Ag}(\alpha-\mathrm{O} \text {-methyl glucose })]^{+}$and $[\mathrm{Ag}(\beta-\mathrm{O} \text {-methyl glucose })]^{+}$ complexes when the cone voltage increases. The ESI/MS/MS spectra displayed in Figure 3 show that both species can be clearly differentiated. 
$<$ Figure 3 $>$

Apart from the formation of $\mathrm{Ag}^{+}$, the principal fragmentations of $[\mathrm{Ag}(\alpha-\mathrm{O}$-methylglucose) $]^{+}$are the loss of methanol (m/z 269) followed by elimination of 110 mass units (m/z 191). In contrast, for the $[\mathrm{Ag}(\beta \text {-O-methyl-glucose })]^{+}$complex, the main loss is silver hydride (m/z 193). The same behavior has been previously reported by Berjeaud et $a l^{8}$ in their study devoted to stereochemically controlled decomposition of silver-cationized methyl glycosides generated by FAB. This suggests that similar structures would be formed in both techniques. A mechanistic approach will be discussed in the later discussion section.

\section{Reactivity of D-glucose, D-galactose and D-fructose with $\mathrm{Cu}^{+}$.}

ESI mass spectra show the presence of abundant protonated and coppered species. As in the case of silver, $\mathrm{Cu}^{+}$-containing ions are discernible by the presence of two ions separated by two mass units (corresponding to ${ }^{63} \mathrm{Cu}$ and ${ }^{65} \mathrm{Cu}$ isotopes). A cone voltage value of $50 \mathrm{~V}$ (that gives the most intense ion of interest) was chosen. The electrospray mass spectra of monosaccharides (1, 2, and 3) in copper(II) chloride solutions, displayed in Figure 4, are characterized by three types of singly charged metallic complexes involving either intact or deprotonated monosaccharides.

$<$ Figure $4>$

- (i) complexes in which the formal oxidation state of copper remained Cu(II) such as [Cu(II)(monosaccharide) $-\mathrm{H}]^{+}$(at $m / z$ 242/244), [Cu(II)(monosaccharide) $\left.-\mathrm{H}+2 \mathrm{H}_{2} \mathrm{O}\right]^{+}$

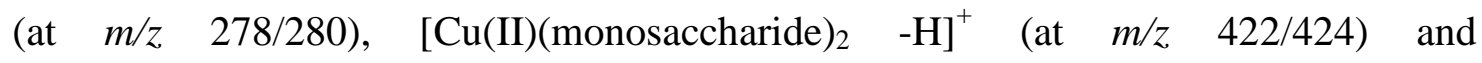
[Cu(II)(monosaccharide) $\left.2-\mathrm{H}+2 \mathrm{H}_{2} \mathrm{O}\right]^{+}$(at $\mathrm{m} / \mathrm{z}$ 458/460).

- $\quad$ (ii) metallic complexes of reduced $\mathrm{Cu}(\mathrm{I})$-adduct ions like $\left[\mathrm{Cu}(\mathrm{I})(\text { monosaccharide) }]^{+}\right.$(at $m / z$ 243/245) and [Cu(I)(monosaccharide) $]^{+}$(at $m / z$ 423/425). Doubly-charged species were never observed. 
- (iii) metallic complexes including metal chloride ion $\mathrm{Cu}(\mathrm{II}) \mathrm{Cl}^{+}$like $\left[\mathrm{Cu}(\mathrm{II}) \mathrm{Cl}(\text { monosaccharide) }]^{+}\right.$(at $\mathrm{m} / \mathrm{z}$ 278-282) and $\left[\mathrm{Cu}(\mathrm{II}) \mathrm{Cl}\left(\text { monosaccharide) }{ }_{2}\right]^{+}\right.$(at $m / z$ 458-462).

The formation under electrospray conditions of a mixture of organometallic species containing copper ions in two different oxidation states, is now well known and has been already reported before by Lavanant et $a l^{30}$ in their studies on peptides-metal complexes and by Turecek et $a l^{31}$ with ternary peptides-metal complexes [Cu(II)(M-H)(bpy) ${ }^{+}$. This phenomenon has been attributed to gas-phase reactions of highly coordinated precursor ions, involving ligand-to-metal electron transfers and/or de-coordination of oxidized ligands. In solution the nature and the geometry of the ligands around copper are know to influence $\mathrm{Cu}(\mathrm{I}) / \mathrm{Cu}(\mathrm{II})$ reduction potential. According to this assumption, the $\mathrm{Cu}(\mathrm{I})$ oxidation state is favored by soft ligands, and being a closed shell $\mathrm{d}^{10}, \mathrm{Cu}(\mathrm{I})$ prefers tetrahedral four- or threecoordinated geometries. By contrast, the complexes containing divalent copper are rather square planar or octahedral. The ratio [Cu(II)(monosaccharide) $\mathrm{H}]^{+} /[\mathrm{Cu}(\mathrm{I})(\text { monosaccharide })]^{+}$was found to depend on nozzle-skimmer voltage variations. At low cone voltages (5-30V), metallic complexes involving $\mathrm{Cu}(\mathrm{II})$ are predominant. On the contrary, high cone voltages lead to a decrease of the $\left[\mathrm{Cu}(\mathrm{II})(\text { monosaccharide) }-\mathrm{H}]^{+}\right.$ abundance whereas that of $\left[\mathrm{Cu}(\mathrm{I})(\text { monosaccharide) }]^{+}\right.$increases. As already encountered for silver, high coordinated species are the precursors of the formation of both species. This is in agreement with the presence of $\left[\mathrm{Cu}(\mathrm{II})(\text { monosaccharide) })_{2}-\mathrm{H}+2 \mathrm{H}_{2} \mathrm{O}\right]^{+}$(at $\mathrm{m} / \mathrm{z} 458 / 460$ ) complexes, which disappear rapidly when the cone voltage increases $(>35 \mathrm{~V})$. It is important to emphasize that $\mathrm{Cu}^{2+}$ is never observed in ESI conditions and that $\mathrm{Cu}^{+}$appears when the intensities of $[\mathrm{Cu}(\mathrm{I})(\text { monosaccharide })]^{+}$and $[\mathrm{Cu}(\mathrm{II}) \text { (monosaccharide) }-\mathrm{H}]^{+}$complexes decrease. The formation of the ions of interest $\left[\mathrm{Cu}(\mathrm{I})(\text { monosaccharide) }]^{+}\right.$at $\mathrm{m} / \mathrm{z} 243 / 245$ and 
[Cu(II)(monosaccharide-H) $]^{+}$at $\mathrm{m} / \mathrm{z} 242 / 244$ can be explained by the decomposition of several possible precursors, i.e., [Cu(II)(monosaccharide) $\left.-\mathrm{H}+2 \mathrm{H}_{2} \mathrm{O}\right]^{+}$at $\mathrm{m} / \mathrm{z} 278 / 280$ and [Cu(II)(monosaccharide) $\left._{2}-\mathrm{H}\right]^{+}$at m/z 422/424 In other words [Cu(II)(monosaccharide) $\left.-\mathrm{H}\right]^{+}$ species which are stable at low energies, could come from highly coordinated species formed in solution, which decompose either in the electrospray source by desolvatation or by fragmentation induced by collision in low energetic conditions. In order to comfort this assumption we have performed the precursor ion spectrum of $\left[{ }^{63} \mathrm{Cu}(\mathrm{II}) \text { (glucose) }-\mathrm{H}\right]^{+}$ion at $\mathrm{m} / \mathrm{z} 242$. The spectrum actually displays several ions at $\mathrm{m} / \mathrm{z} 260,278,302,332,362,422$, 458, which correspond to $\left[{ }^{63} \mathrm{Cu}(\mathrm{II})\right.$ (glucose) $\left.\left.-\mathrm{H}+\mathrm{H}_{2} \mathrm{O}\right]\right]^{+},\left[{ }^{63} \mathrm{Cu}(\mathrm{II}) \text { (glucose) }-\mathrm{H}+2 \mathrm{H}_{2} \mathrm{O}\right]^{+}$, $\left.\left[{ }^{63} \mathrm{Cu}(\mathrm{II}) \text { (glucose) }\right)_{2}-\mathrm{H}-\mathrm{C}_{4} \mathrm{H}_{8} \mathrm{O}_{4}\right]^{+},\left[{ }^{63} \mathrm{Cu}(\mathrm{II})(\text { glucose) })_{2}-\mathrm{H}-\mathrm{C}_{3} \mathrm{H}_{6} \mathrm{O}_{3}\right]^{+},\left[{ }^{63} \mathrm{Cu}\right.$ (II)(glucose) $2-\mathrm{H}-$ $\left.\mathrm{C}_{2} \mathrm{H}_{4} \mathrm{O}_{2}\right]^{+},\left[{ }^{63} \mathrm{Cu}(\mathrm{II})(\text { glucose })_{2}-\mathrm{H}\right]^{+}$and $\left[{ }^{63} \mathrm{Cu}(\mathrm{II})(\text { glucose })_{2}-\mathrm{H}+\mathrm{H}_{2} \mathrm{O}\right]^{+}$respectively. The $[\mathrm{Cu}(\mathrm{I}) \text { (monosaccharide) }]^{+}$complexes are generated only in the gas phase, under higher energetic ways, from the decomposition of tetra- or hexa-coordinated $\mathrm{Cu}(\mathrm{II})$ complexes. The corresponding ESI spectrum shows a somewhat complex pattern, because a set of four peaks appears, representing the overlapping isotopic distributions of $\left[\mathrm{Cu}(\mathrm{I})(\text { monosaccharide) }]^{+}\right.$and $\left[\mathrm{Cu}(\mathrm{II})(\text { monosaccharide) }-\mathrm{H}]^{+}\right.$with only one unit mass difference between the two adduct ions. Consequently, the selection of the ion of interest for CID experiments has, to be carried out with caution.

That said, the most conspicuous fact of Figure 4 is that the ESI-MS spectrum for each hexose (1, 2 and $\mathbf{3})$ leads to rather similar ions but with different intensities. Although in the case of D-fructose (3), an additional ion at $\mathrm{m} / \mathrm{z} 332 / 334$ appears. Hence, as in the case of silver cationization, the positive ion ESI spectra of coppered-complexes do not really allow the aldoses ( $\mathbf{1}$ and $\mathbf{2}$ ) and the ketose (3) to be differentiated. 
The low-energy CID spectra of $\left[{ }^{63} \mathrm{Cu}(\mathrm{I})(\text { monosaccharide) }]^{+}\right.$adduct ions recorded at a collision energy of $20 \mathrm{eV}$ show an amazing reactivity. The copper cation is able to induce activation of practically all C-C and C-O bonds resulting in many fragmentation pathways. As illustrated in Figure 5, the CID spectra for the three isomers [Cu(glucose) $]^{+},[\mathrm{Cu} \text { (galactose) }]^{+}$ and $[\mathrm{Cu}(\text { fructose })]^{+}(\mathrm{m} / \mathrm{z} 243)$ are rather similar.

\section{$<$ Figure 5 $>$}

Three fragmentation pathways leading to intense ions at $\mathrm{m} / \mathrm{z} 123, \mathrm{~m} / \mathrm{z} 153$ and $\mathrm{m} / \mathrm{z} 225$, corresponding to $\left[\mathrm{Cu}(\mathrm{I})\left(\text { monosaccharide) }-\mathrm{C}_{4} \mathrm{H}_{8} \mathrm{O}_{4}\right]^{+}\right.$, $\left[\mathrm{Cu}(\mathrm{I}) \text { (monosaccharide) }-\mathrm{C}_{3} \mathrm{H}_{6} \mathrm{O}_{3}\right]^{+}$, and $\left[\mathrm{Cu}(\mathrm{I}) \text { (monosaccharide) }-\mathrm{H}_{2} \mathrm{O}\right]^{+}$respectively, dominate. Three other fragment ions at $\mathrm{m} / \mathrm{z} 183$, m/z 147 and $m / z$ 135, resulting from $\mathrm{C}_{2} \mathrm{H}_{4} \mathrm{O}_{2}, \mathrm{C}_{2} \mathrm{H}_{4} \mathrm{O}_{2}+2 \mathrm{H}_{2} \mathrm{O}$ and $\mathrm{C}_{3} \mathrm{H}_{6} \mathrm{O}_{3}+\mathrm{H}_{2} \mathrm{O}$ eliminations are smaller. From these results we can conclude that the use of copper salt does not allow a clear-cut distinction between D-glucose, D-galactose and D-fructose, neither from the positive ion ESI spectra nor from the ESI-MS/MS spectra.

\section{Reactivity of O-methyl- $\alpha$-D-glucoside and $\mathrm{O}$-methyl- $\beta$-D-glucoside with $\mathrm{Cu}^{+}$.}

The ESI-MS/MS spectrum of $\left[{ }^{63} \mathrm{Cu}(\mathrm{O} \text {-methyl- } \alpha \text {-D-glucose })\right]^{+}(\mathrm{m} / \mathrm{z} 257)$ is given in Figure 6. We can see that the decomposition processes of methyl glycoside are somewhat identical to those of $\left[{ }^{63} \mathrm{Cu}(\mathrm{D} \text {-glucose })\right]^{+}$. The principal fragment ions observed in the ESI/MS/MS spectrum correspond to $\left[{ }^{63} \mathrm{Cu}(\mathrm{O}-\text {-methyl- } \alpha \text {-D-glucose })-\mathrm{C}_{5} \mathrm{H}_{10} \mathrm{O}_{4}\right]^{+}(\mathrm{m} / \mathrm{z} 123)$ and $\left[{ }^{63} \mathrm{Cu}(\mathrm{O}-\right.$ methyl- $\alpha$-D-glucose) $\left.-\mathrm{C}_{4} \mathrm{H}_{8} \mathrm{O}_{3}\right]^{+}\left(\mathrm{m} / \mathrm{z}\right.$ 153) (similar to $\mathrm{C}_{4} \mathrm{H}_{8} \mathrm{O}_{4}$ and $\mathrm{C}_{3} \mathrm{H}_{6} \mathrm{O}_{3}$ losses observed with D-glucose). Dehydration is replaced by methanol elimination giving rise to the $\mathrm{m} / \mathrm{z} 225$ ion. In turn this latter species fragments according to two successive eliminations of $\mathrm{C}_{2} \mathrm{H}_{4} \mathrm{O}_{2}$ and $\mathrm{H}_{2} \mathrm{O}$ giving rise to the ion 147 . 
The ESI/MS spectra of a solution of O-methyl- $\beta$-D-glucose and copper salts recorded at different cone voltage do not present signals for $[\mathrm{Cu}(\mathrm{O}-\text {-methyl- } \beta \text {-D-glucose })]^{+}$adducts and only the deprotonated $\mathrm{Cu}(\mathrm{II})$ species was observed. So, the possible differentiation cannot be explored. Now, if we compare the reactivity of both $[\mathrm{Cu}(\mathrm{II})(\mathrm{O}-\text { methyl- } \alpha \text {-D-glucose })-\mathrm{H}]^{+}$and $\left[\mathrm{Cu}(\mathrm{II})(\mathrm{O}-\text { methyl- } \beta \text {-D-glucose) }-\mathrm{H}]^{+}\right.$complexes the corresponding spectra (see Figure 7 ) are also similar. This indicates that both copper anomers give rise to a common structure. These features will be analyzed in the next discussion part.

$<$ Figure 7 $>$

\section{DISCUSSION}

\section{Low-energy CID spectra of metal-monosaccharides ions}

Understanding the reactivity of metal-monosaccharides complexes implies in a first step, the identification among the numerous species that can result from cationization, of the most probable structures (related with the most favoured coordination site of the cation) responsible for the observed reactivity. Metal cations may, in principle, bind to any of the electron-rich centers of monosaccharides, including the hemiacetal oxygen atom. The reactivity of these complexes can result in fact from a mixture of different structures in which the cation $\mathrm{Ag}^{+}$or $\mathrm{Cu}^{+}$can interact not only with different sites but also with different types of coordination and even with open structures as already reported. ${ }^{19}$ On the basis of several theoretical approach, several authors ${ }^{\mathbf{1 7 - 2 0}}$ have shown that the cationization of such neutral species by a metal cation is governed by two criteria: the first one concerns the mode of coordination of the metal cation, which must be as great as possible (three and even four) and the second one is related with the preservation of a maximum of intramolecular hydrogen bonds. Thus, some peculiar structures can be retained as starting point, in order to rationalize the reactivity experimentally observed. Some trends can be deduced from several theoretical investigations 
about the gas-phase interaction between metallic cations and monosaccharides. Cerda et al. have carried out experiments and calculations concerning the complexation of $\mathrm{Na}^{+}$ions with a series of hexoses ${ }^{\mathbf{1 3}}$, in their pyranose conformation. These authors have shown that for $\mathrm{Na}^{+}$ monodentate structures are higher in energy than multidentate conformers. The most stable geometries correspond to tri- or tetradentate [Na-D-glucose $]^{+}$complexes, in which the sodium ion is bound to the hydroxymethyl group, the hemiacetal oxygen, and at least one additional hydroxyl group, which in the case of glucose is the anomeric one. Similar results have been reported about the interaction of $\mathrm{Ca}^{2+}$ with $\beta$-D-glucose ${ }^{17}$ or $\beta$-D-mannose. ${ }^{18}$ Experimental and theoretical investigations of the reaction between glucose and $\mathrm{Cu}^{+}$and $\mathrm{Pb}^{2+}$ in the gas phase have been recently reported. ${ }^{19,20}$ From these studies it seams clear that all metal cations follow similar coordination schemes.

So, in the following discussion we will take as our starting structures the tri-coordinated ones, knowing that, very likely, other structures can also contribute to the observed reactivity.

$[\mathrm{X}+\mathrm{D} \text {-monosaccharide }]^{+}(\mathrm{X}=\mathrm{Ag}, \mathrm{Cu})$ complexes dissociate principally according to four channels, dehydration and losses of $\mathrm{C}_{2} \mathrm{H}_{4} \mathrm{O}_{2}, \mathrm{C}_{3} \mathrm{H}_{6} \mathrm{O}_{3}$ and $\mathrm{C}_{4} \mathrm{H}_{8} \mathrm{O}_{4}$ molecules. In the case of copper-complexes, this latter elimination, giving rise to $\left[\mathrm{CuC}_{2} \mathrm{H}_{4} \mathrm{O}_{2}\right]^{+}(\mathrm{m} / \mathrm{z} 123)$ ion, is the major process (Figure 5). Loss of water may involve any of the hydroxyl groups. Nevertheless, comparison with results obtained for O-methyl-D-glucose (4), indicates that the anomeric hydroxyl could be principally concerned. As a matter of fact, when a methoxy group replaces the anomeric hydroxyl, loss of water is no longer observed for both cations and is replaced by methanol elimination. Consequently, loss of water would imply almost exclusively the anomeric hydroxyl. Nevertheless it has to be considered that the experiments are based in methyl derivatives of glucopyranose and the presence of the extra methyl can modified the stability of the precursors and of the products ions. 
Eliminations of organic molecules of general formula $\mathrm{C}_{n} \mathrm{H}_{2 n} \mathrm{O}_{n}$, involve the cleavage of the pyranose ring and are observed either with silver and copper complexes. Analysis of the spectra shows that both cations induce different decomposition pathways. Formation of the $\left[\mathrm{CuC}_{2} \mathrm{H}_{4} \mathrm{O}_{2}\right]^{+}$ion $(\mathrm{m} / \mathrm{z}$ 123) is the predominant process for all copper-complexes, whereas $\left[\mathrm{AgC}_{3} \mathrm{H}_{6} \mathrm{O}_{3}\right]^{+}$ion (m/z 197) is favored for silver. A careful comparison with results obtained for O-methyl-D-glucose (see Figure 6) provides useful information for copper complexes. When the anomeric hydroxyl is replaced by a methoxy group, $\left[\mathrm{CuC}_{2} \mathrm{H}_{4} \mathrm{O}_{2}\right]^{+}$ion $(\mathrm{m} / \mathrm{z} 123)$ remains the base peak, showing that the anomeric center is involved in the fragmentation. One may reasonably assume that $\mathrm{C}_{2} \mathrm{H}_{4} \mathrm{O}_{2}$ molecule bounded to copper species involves $\mathrm{C}(5)$ and $\mathrm{C}(6)$ carbon atoms and consequently hydroxymethyl and hemiacetal groups for D-glucose and D-galactose. To demonstrate the mechanisms of decomposition for each monosaccharide, an extensive labeling study is required. Further experimental and theoretical studies are planed for this purpose. Nevertheless we can note that the behavior of the three silver- and coppermonosaccharides generated by $\mathrm{FAB}^{\mathbf{1 0}}$ or ESI ionization is different. While metastable decompositions of Ag adducts, which involve $\mathrm{H}_{2}$ and water eliminations, does not allow a clear-cut distinction, the three selected copper cationized monosaccharides exhibit specific dissociation patterns and are easily distinguished. Thus, conclusions are inverted. Moreover, it is clear that cationized species dissociating under FAB/MIKES conditions have lower energy content than those generated by ESI and subject to low-energy CID experiments. In these latter conditions one can observe not only C-C and C-O cleavages but also successive fragmentations, which can arise from cyclic or even opened structures. The abundances of the ESI/MS/MS principal ions are summarized in Table 1 and a fragmentation pattern for $[\mathrm{Cu}(\text { glucose })]^{+}$is presented in Scheme 2.

$<$ Table 1>, <Scheme 2>

\section{Low-energy CID spectra of metal-methyl glucosides ions}


Loss of metal hydride, yielding the ion at $\mathrm{m} / \mathrm{z} 193$, is a specific fragmentation pathway for

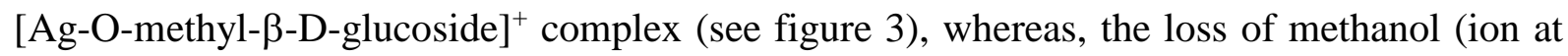
$\mathrm{m} / \mathrm{z}$ 269) followed by successive eliminations of $\mathrm{C}_{2} \mathrm{H}_{4} \mathrm{O}_{2}$ and $\mathrm{H}_{2} \mathrm{O}$, leading to ion at $\mathrm{m} / \mathrm{z} 191$, characterizes the [Ag-O-methyl- $\alpha$-D-glucoside $]^{+}$isomer. Previous studies with $\beta$-O-methylD-glucose-1- $d_{1}$, indicate that the $C(1)$ hydrogen atom is exclusively eliminated ${ }^{8}$. These findings suggest that this fragmentation clearly depends on the $C(1)$ stereochemistry, and is particularly important for the $\beta$ anomer. Elimination of AgH certainly implies structures in which the metal cation interacts differently with the glycoside. Attachment of the metal below the plane of the pyranose ring might be favored because of possible hydrogen bonds hindering the upper face of the ring. The metallic cation then might interact with different basic sites of the lower face $(\mathrm{C}(2)$ hydroxyl and others) leading to a multidentate structure, from which $\mathrm{C}(1)$ hydrogen atom is pulled away followed by $\mathrm{Ag}^{+}$leaving. In the same previous study, experiments involving labeled O-methyl- $\alpha$-D-glucose compounds demonstrated that the hydrogen atom eliminated together with the methoxy group is that of the $C(2)$ hydroxyl group. This means that this specific reactivity could imply preferential structures that can be predicted by a theoretical survey. The aim of such approach is not to explore the total and quite wide energy surfaces of these systems but to propose some structures that can play a significant role in the observed reactivity, keeping in mind that other structures could be also involved. Given the facts that the metallic cations may in principle attach to any basic center, a considerable number of possible geometries should be considered. So, we have restricted our survey only to structures that could account for methanol and AgH losses from both Omethyl- D-glucose anomers. Among all of the possible structures for the $\alpha$ and $\beta$ glucosides, we have taken as the most stable the pyranose conformations presented in Figure 8. Similarly to what has been described for glucose, ${ }^{19}$ our calculations predict the most stable $\alpha$ and $\beta$ anomers ( $\boldsymbol{\alpha}-\mathbf{4}$ and $\boldsymbol{\beta}-\mathbf{5})$ to be nearly degenerated (the former being $5.4 \mathrm{~kJ} / \mathrm{mol}$ more stable). 
Nevertheless, for methyl-glucoside the $\alpha$ anomer is the most stable, contrary to the glucose. The total and relative energies are given in Table 2.

$<$ Figure $8>$; $<$ Table 2>.

The geometries of the structures arising by $\mathrm{Cu}^{+}$and $\mathrm{Ag}^{+}$attachment (above and below the plane) that we have considered of interest, are displayed in Figure 9 and 10 and the corresponding energies are gathered in Table 2.

$<$ Figure 9>;<Figure 10>;

First of all, we have assumed that the structures of both anomers retain their pyranose chair form upon complexation. Among the numerous structures explored, five of them, bidendate and tridendate, have been selected. For both silver and copper complexes, the global minima are the dicoordinated $\boldsymbol{\alpha}-\mathbf{4} \mathbf{A C \mathbf { u } ^ { + }}$ and $\boldsymbol{\alpha - 4} \mathbf{A} \mathbf{A g}^{+}$structures in which the metal cation is attached to oxygen atoms 3 and 4 . The corresponding $\boldsymbol{\beta}-\mathbf{5} \mathbf{A C \mathbf { C u } ^ { + }}$ and $\boldsymbol{\beta}-\mathbf{5} \mathbf{A A g} \mathbf{g}^{+}$structures are estimated to be less stable by 45.6 and $44.6 \mathrm{~kJ} \mathrm{~mol}^{-1}$ respectively. Tricoordinated structures $\beta$-5BCu $\mathbf{u}^{+}$ and $\boldsymbol{\beta}-\mathbf{5 B A g}{ }^{+}$also correspond to very stable conformers, which lie 18.1 and $25.0 \mathrm{~kJ} \mathrm{~mol}^{-1}$ above the corresponding minimum global. The distortion in the sugar ring, induced by the metal ion association could explain this stability difference. Nevertheless from Table 2 we can see that the other selected structures are competitive in energy and can compete when discussing their possible participation in the observed reactivity.

Let us consider now the reactivity. For the methanol loss from the $\alpha$ anomer, structures $\alpha$ $\mathbf{4 B C u} \mathbf{u}^{+}$and $\boldsymbol{\alpha}-\mathbf{4 B A g} \mathbf{g}^{+}$in which the metal cations, $\left(\mathrm{Cu}^{+}\right.$or $\left.\mathrm{Ag}^{+}\right)$interact with $\mathrm{O}(2)$ and $\mathrm{O}(3)$ hydroxyl groups, might be good candidates even if structures involving hydroxymethyl oxygen atom $\mathrm{O}(6)$ and the hemiacetal oxygen atom cannot be discarded. Figure 9 and 10 reveal that the two structures $\boldsymbol{\alpha}-\mathbf{4 B C \mathbf { u } ^ { + }}$ and $\boldsymbol{\alpha - 4 B A g ^ { + }}$ display similar geometries, only the 
metal-O bonding distances, which range from $2.045 \AA$ and $2.033 \AA$ for $\mathrm{Cu}^{+}$to $2.350 \AA$ and $2.339 \AA$ for $\mathrm{Ag}^{+}$differ. These trends have been already reported ${ }^{32}$ and explained in terms of orbital overlapping and electrostatic interactions. Actually, if $\mathrm{O}_{-} \mathrm{Ag}^{+}$bonding has a pure electrostatic character, $\mathrm{O}-\mathrm{Cu}^{+}$bonding presents a "covalent part". Knowing that the $\mathrm{Ag}^{+}$ radius of is bigger than that of $\mathrm{Cu}^{+}\left(\mathrm{R}_{\mathrm{Ag}^{+}}=1,26 \AA, \mathrm{R}_{\mathrm{Cu}^{+}}=0.96 \AA\right)$, the interaction distances O$\mathrm{Ag}^{+}$are thus increased by $0.3 \AA$. The hydrogen atom involved in methanol elimination has been identified previously as being the $\mathrm{O}(2)-\mathrm{H}^{\mathbf{8}}$, we can see in fact in $\boldsymbol{\alpha}-\mathbf{4 B C \mathbf { u } ^ { + }}$ and $\boldsymbol{\alpha}-\mathbf{4 B} \mathbf{A} \mathbf{g}^{+}$ structures, that this hydrogen atom interacts with the methoxy oxygen atom through a strong hydrogen bond (2.017 $\AA$ and 2. $043 \AA$ respectively). Moreover, when the transfer of this hydrogen atom is initiated (by a computational scan of the $\mathrm{O}(2)-\mathrm{H}$ bond) the $\mathrm{C}(1)-\mathrm{OCH}_{3}$ anomeric bond is greatly activated. These findings are in agreement with experimental results and allow to propose a fragmentation pathway for methanol elimination, displayed in Scheme 3.

\section{$<$ Scheme 3>}

Concerning the AgH elimination, three $\beta$-structures (see Figure 10) have been selected, $\boldsymbol{\beta}-\mathbf{5 B A g} \mathbf{g}^{+}, \boldsymbol{\beta}-\mathbf{5 C A g} \mathbf{g}^{+}$and $\boldsymbol{\beta}-\mathbf{5 D A g} \mathbf{g}^{+}$. The tri-coordinated complex $\boldsymbol{\beta}-\mathbf{5 B A g} \mathbf{g}^{+}$contains $\mathrm{Ag}^{+}$ bound to hemiacetal oxygen atom, the hydroxymethyl group and the methoxy one. One can assume that this structure is not involved in AgH loss in so far as the hydrogen atom implicated is the anomeric hydrogen, which is in the lower plane and at a distance of $3.577 \AA$. In $\boldsymbol{\beta}$-5CAg ${ }^{+}$complex, the cation is bi-ligated, it interacts with $\mathrm{O}(2)$ and the oxygen atom of the methoxy group, in this structure the Ag-H distance is about 3.357 $\AA$. Finally, the structure, $\boldsymbol{\beta}$-5DAg ${ }^{+}$, presents the most favorable configuration for hydrogen abstraction. In this tricoordinated structure, $\mathrm{Ag}^{+}$is bound in the bottom face, to the hemiacetal oxygen atom and to the two hydroxyl groups at $\mathrm{O}(2)$ and $\mathrm{O}(4)$ with an average Ag-O bond of $2.45 \AA$. The anomeric hydrogen atom is in the lower part at a distance of $3.170 \AA$. Thus, these two less 
stable structures $\boldsymbol{\beta}-\mathbf{5 C A g}{ }^{+}$and $\boldsymbol{\beta}-\mathbf{5 D A g} \mathbf{g}^{+}$could be the most favorable candidates for $\mathrm{AgH}$ elimination (see Scheme 3).

In our experimental source conditions and in spite of several attempts, the ion corresponding to $[\boldsymbol{\beta}-\mathbf{5 C u}]^{+}$is absent. That means that either the $\mathrm{CuH}$ elimination is very efficient in the source or the highly coordinated precursors ions do not lead to $[\boldsymbol{\beta}-5 \mathbf{C u}]^{+}$ formation. The calculations have been nevertheless performed in order to compare the stabilities of corresponding copper complexes. The structures displayed in Figure 9 show the same energetic and structural features, i.e.: three-coordinated species are favored (see Table 2) and the $\mathrm{Cu}-\mathrm{O}$ bonds are shortened by 0.3 to $0.5 \AA$. These structural differences are reflected in relative affinities of the various binding modes. It is found that $\mathrm{Cu}^{+}$affinities are approximately $100 \mathrm{~kJ} / \mathrm{mol}$ stronger than $\mathrm{Ag}^{+}$ones. The evaluated binding energies range from $334 \mathrm{~kJ} / \mathrm{mol}$ to $285 \mathrm{~kJ} / \mathrm{mol}$ for copper ion interactions and from $239 \mathrm{~kJ} / \mathrm{mol}$ to $181 \mathrm{~kJ} / \mathrm{mol}$ for corresponding silver complexes (these values do not take into account the deformation energies induced by the cationization).

Now, if we consider the reactivity of $[\mathrm{Cu}(\mathrm{II})(\mathrm{O}-\text { methyl- } \alpha \text {-D-glucose })-\mathrm{H}]^{+}$and $[\mathrm{Cu}(\mathrm{II})(\mathrm{O}-$ methyl- $\beta$-D-glucose) $-\mathrm{H}]^{+}$isomers (see Figure 7 ), the similarity of the spectra seems to indicate, as already mentioned, that both copper anomers give rise to a common structure. This species decomposes by loosing $73 \mathrm{u}$ corresponding to the elimination of a radical: namely $\mathrm{C}_{3} \mathrm{H}_{5} \mathrm{O}_{2} \cdot$ This implies that the common structure results from the elimination of the anomeric hydrogen atom. The loss of the radical $\mathrm{C}_{3} \mathrm{H}_{5} \mathrm{O}_{2}{ }^{\circ}$, which is accompanied by the reduction of $\mathrm{Cu}(\mathrm{II})$, gives rise to the major product ion : the $\left[\mathrm{Cu}(\mathrm{I}) \mathrm{C}_{4} \mathrm{H}_{8} \mathrm{O}_{4}\right]^{+}$complexe at $\mathrm{m} / \mathrm{z} 183$ (see Scheme 4). Such a radical elimination has been already described by Lavanant et $a l^{29}$ and by Turecek et $a l^{30}$. 


\section{CONCLUSION}

From the results obtained during our electrospray/tandem mass spectrometry study of silver and copper-coordinated monosacchrides, D-glucose, D-galactose, D-fructose, Omethyl- $\alpha$-D-glucose and O-methyl- $\beta$-D-glucose, we can conclude that cationization by $\mathrm{Ag}^{+}$ allows to differentiate the three monosaccharides whereas the complexes formed by association of $\mathrm{Cu}^{+}$and $\mathrm{Cu}^{2+}$ to the three monosacharides display a similar reactivity that prevents stereoisomer distinction. Silver adduct-ions of both anomeric $\alpha$ - and $\beta$ - O-methyl-Dglucoses generated by electrospray present the same decomposition pathways that those observed under FAB/MIKES conditions, that is a loss of methanol for the $\alpha$-anomer and a loss of silver hydride for the $\beta$-anomer. These differences of behavior have been analyzed by means of a theoretical approach. The calculations allowed to propose starting structures and fragmentation schemes, which can account for these specific fragmentations, and to evaluate $\mathrm{Cu}^{+}$and $\mathrm{Ag}^{+}$binding energies. 


\section{REFERENCES}

1. D. M. Whitfield, S. Stojkovski, B. Sarkar, Metal Coordination to Carbohydrates. Structures and Functions. Coordin. Chem. Rev. 122, 171-225 (1993).

2. S. Yano, M. Otsuka, Metal Ions in Biological Systems, Ed. by A. Sigel and H. Sigel, Marcel Dekker, New-York, Vol. 32, p. 28 (1996).

3. Z. Zhou, S. Ogden, Linkage Position determination In Oligosaccharides: MS/MS Study of Lithium-Cationized Carbohydrates. J. A. Leary, J. Org. Chem. 55, 5444-5446 (1990).

4. A. R. Dongré, V. H. Wysocki, Linkage Position of Lithium-Cationized Disaccharides by Surface-Induced Dissociation Tandem Mass Spectrometry. Org. Mass Spectrom. 29, 700702 (1994).

5. E. M. Sible, S. P. Brimmer, J. A. Leary, Interaction of First Row Transition Metals with

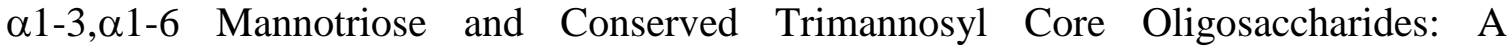
Comparative Electrospray Ionization Study of Doubly and Singly Charged Complexes. $J$. Am. Soc. Mass Spectrom. 8, 32-42 (1997).

6. M. R. Asam, G. L. Glish, Tandem Mass Spectrometry of Alkali Cationized Polysaccharides in a Quadrupole Ion Trap. J. Am. Soc. Mass Spectrom. 8, 987-995 (1997).

7. S. König, J. A. Leary, Evidence for Linkage Position Determination in Cobalt Coordinated Pentasaccharides Using Ion Trap Mass Spectrometry. J. Am. Soc. Mass Spectrom. 9, 1125-1134 (1998).

8. J. M. Berjeaud, F. Couderc, J. C. Promé, Stereochemically controlled decompostion of silver-cationized methyl glycosides Org. Mass Spectrom. 28, 455-458 (1993).

9. J-Y. Salpin, J. Tortajada, Experimental an theoretical study of the gas-phase reactivity of $\mathrm{Pb}^{2+}$ cations with monosaccharides. Adv. Mass Spectrom. 15, 735-736 (2001).

10. J-Y. Salpin, L. Boutreau, V. Haldys, J. Tortajada, Gas-Phase Reactivity of Glycosides and Methyl Glycosides with $\mathrm{Cu}^{+}, \mathrm{Ag}^{+}$and $\mathrm{Pb}^{2+}$ ions by Fast-Atom Bombardment and Tandem Mass Spectrometry. Eur. J. Mass Spectrom. 7, 321-330 (2001). 
11. J-Y. Salpin, J. Tortajada, Structural Characterization of Hexoses and Pentoses Using Lead Cationization. An Electrospray Ionization and Tandem Mass Spectrometric Study. J. Mass Spectrom. 37, 379-388 (2002).

12. (a) V. Carlesso, C. Afonso, F. Fournier, J-C. Tabet, Stereochemical effects from doublycharged iron clusters for the structural elucidation of diastereomeric monosaccharides using ESI/IT-MS. Int. J. Mass Spectrom. 219, 559-575 (2002).

(b) K. P. Madhusudanan, T. S. Dhami, S. Katiyar, S. N. Suryawanshi, $\mathrm{Li}^{+}-$and $\mathrm{Ag}^{+}-$ Cationized Per-O-acetyl- and Per-O-benzyl- $\alpha$-thioglycosides: a Collision-Induced Decomposition Study. Org. Mass Spectrom. 29, 238-246 (1994).

13. (a) B. A. Cerda, C. Wesdemiotis, Thermochemistry and Structures of $\mathrm{Na}^{+}$Coordinated Mono- and Disaccharide stereoisomers. Int. J. Mass Spectrom. 189, 189-204 (1999).

(b) E. Botek, J.L. Debrun, B. Hakim, L. Morin-Allory, Attachment of alkali cations on $\beta$ D-glucopyranose: matrix-assisted laser desorption/ionization time of flight studies and $a b$ initio calculations. Rapid Commun.Mass Spectrom., 15, 273-276 (2001).

(c) A. Antonopoulos, P. Bonnet, E. Botek, J.L. Debrun, B. Hakim, B. Herbreteau, L. Morin-Allory, Study of the attaachment of $\mathrm{Na}+$ on glucose and on some of its methylated derivatives. Rapid Commun.Mass Spectrom., 17, 122-125 (2003).

14. S. P. Gaucher, J. A. Leary, Stereochemical Differentiation of Mannose, Glucose, Galactose, and Talose Using Zinc(II) Diethylenetriamine and ESI-Ion Trap Mass Spectrometer. Anal. Chem. 70, 3009-3014 (1998).

15. H. Desaire, J. A. Leary, Differentiation of Diastereoisomeric $N$-Acetylhexosamine Monosaccharides Using Ion Trap Tandem Mass Spectrometry. Anal. Chem. 71, 19972002 (1999).

16. (a) G. Smith, A. Kaffashan, J. A. Leary, Influence of Coordination Number and Ligand Size On the Dissociation Mechanisms of Transition Metal-Monosaccharide Complexes. Int. J. Mass Spectrom. 182/183, 299-310 (1999).

(b) H. Desaire, M. D. Leavell, J. Leary, Solvent Effects in Tandem Mass Spectrometry: Mechanistic Studies Indicating How a Change in Solvent Conditions and $\mathrm{PH}$ can Dramatically Alter CID spectra, J. Org. Chem. 67, 3693-3699,(2002). 
17. (a) K. A. Jebber, K. Zhang, C. J. Cassady, A. Chung-Phillips, Ab initio and Experimental studies of protonation of Glucose in the Gas Phase. J. Am. Chem. Soc. 118, 10515-10524, (1996).

(b) Y.J. Zeng, R.L. Ornstein, J.A. Leary, A Density Functional Theory Investigation of Metal Ion Binding Sites in Monosacccharides. J. Mol. Struct. (Theochem) 389, 233-240 (1997).

(c) B. Ma, H. F. Schaeffer III, N. L. Allinger, Theoretical studies of the potential Energy Surfaces and Compositions of Aldo-and Ketohexoses, J. Am. Chem. Soc. 120, 34113422, (1998).

(d) M. Hoffmann, J. Rychlewski, Effects of Substituting a $\mathrm{OH}$ by a F Atom in DGlucose. Ab Initio and DFT Analysis, J. Am. Chem. Soc. 123, 2308-2316, (2001).

18. C. H. S. Wong, F. M. Siu, N. L. Ma, C. W. Tsang, Interaction of $\mathrm{Ca}^{2+}$ with Mannose: a Density Functional Study. J. Mol. Struct. (Theochem) 536, 227-234 (2001).

19. M. Alcami, A. Luna, O. Mó, M. Yáñez, L. Boutreau, J. Tortajada, Experimental and Theoretical Investigation of The Reactions Between Glucose and $\mathrm{Cu}^{+}$in the Gas Phase. J. Phys. Chem. A 106, 2641-2651 (2002).

20. J-Y. Salpin, J. Tortajada, Gas-phase reactivity of Lead(II) ions with D-glucose. A combined electrospray ionization mass spectrometry and theoretical study J. Phys. Chem. A 107, 2943-2953 (2003).

21. (a) J.J.P. Stewart, Optimization of Parameters for Semiempirical Methods J. Comput. Chem. 10, 209-220 (1989).

(b) A. D. Becke, Density Functional Thermochemistry .3. The Role of Exact Exchange. J. Chem. Phys. 98, 5648-5652 (1993).

(c) C. Lee, W.Yang, R. G. Parr, Development of the Colle-Salvetti correlation-energy formula into a functional of the electron density. Phys. Rev. B 37, 785-789 (1988).

22. M. C., Holthausen, C. Heineman, H. H. Cornehl, W. Koch. H. Schwarz, The performance of density-functional/Hartree-Fock hybrid methods: Cationic transition-metal methyl complexes $\mathrm{MCH}_{3}{ }^{+}$(M=Sc-Cu,La,Hf-Au). J. Chem. Phys. 102, 4931-4941 (1995).

23. C. Adamo, F. Lelj, A hybrid density functional study of the first-row transition-metal monocarbonyls J. Chem. Phys. 103, 10605-10613 (1995). 
24. M. R. A. Blomberg, P. E. M. Siegbahn, M. Svensson, Comparisons of results from parametrized configuration interaction (PCI-80) and from hybrid density functional theory with experiments for first row transition metal compounds. J.Chem. Phys. 104, 9546-9554 (1996).

25. L. Rodríguez-Santiago, M. Sodupe, V. Branchadell, Comparison of density functional and coupled cluster methods in the study of metal-ligand systems: $\mathrm{Sc}-\mathrm{CO}_{2}$ and $\mathrm{Cu}-\mathrm{NO}_{2}$. J. Chem. Phys. 105, 9966-9971 (1996).

26. C. W. Bauschlicher, A. Ricca, H. Partridge, S. R. Langhoff, in Recent Advances in Density Functional Theory, Part II; D. P. Chong, Ed.; World Scientific Publishing Company: Singapore 1997

27. P.J. Hay, R. W. Wadt, Ab initio effective core potentials for molecular calculations. Potentials for K to Au including the outermost core orbitals J. Chem. Phys. 82, 299-310 (1985).

28. (a) R. H. Hertwig, W. Koch, D. Schröder, H. Schwarz, J. Hrusák, P. Schwerdtfeger, A Comparative Computational Study of Cationic Coinage Metal-Ethylene Complexes $\left(\mathrm{C}_{2} \mathrm{H}_{4}\right) \mathrm{M}^{+}(\mathrm{M}=\mathrm{Cu}, \mathrm{Ag}$, and Au) J. Phys. Chem. 100, 12253-12260 (1996).

(b) B. Amekraz, J. Tortajada; J-P. Morizur, A. I. González, O. Mó, M. Yáñez, Acetamidine- $\mathrm{Mg}^{+}(\mathrm{S}-2)$ complexes; The performance of different exchange and correlation functionals. J. Mol. Struct. (THEOCHEM) 371, 313-324 (1996).

29. (a) Hyperchem release 6.01 for Windows; Hypercube,Inc., 1999

(b)Gaussian 98, Revision A.7, M.J. Frisch, G.W. Trucks, H.B. Schlegel, G.E. Scuseria, M.A. Robb, J.R. Cheeseman, V.G. Zakrzewski, J.A Montgomery Jr., R.E. Stratmann, J.C. Burant, S. Dapprich, J.M. Millam, A.D. Daniels, K.N. Kudin, M.C. Strain, O. Farkas, J. Tomasi, V. Barone, M. Cossi, R.Cammi, B. Mennucci, C. Pomelli, C. Adamo, S. Clifford, J. Ochterski, G.A. Petersson, P.Y. Ayala, Cui, Q. K. Morokuma, D.K. Malick, A.D. Rabuck, K. Raghavachari, J.B. Foresman, J. Cioslowski, J.V. Ortiz, A.G. Baboul, B.B. Stefanov, G. Liu, A. Liashenko, P. Piskorz, I. Komaromi, R. Gomperts, R.L. Martin, D.J. Fox, T. Keith, M.A. Al-Laham, C.Y. Peng, A. Nanayakkara, C. Gonzalez, M. Challacombe, P.M.W. Gill, B. Johnson, W. Chen, M.W. Wong, J.L. Andres, C. Gonzalez, M. Head-Gordon, E.S. Replogle, and J.A. Pople, Gaussian, Inc., Pittsburgh PA, (1998). 
30. a). H. Lavanant; E. Hecquet and Y. Hoppilliard, Complexes of L-histidine with $\mathrm{Fe}^{2+}$, $\mathrm{Co}^{2+}, \mathrm{Ni}^{2+}, \mathrm{Cu}^{2+}, \mathrm{Zn}^{2+}$ studied by electrospray ionization mass spectrometry. Int. J. Mass Spectrom. 185-187, 11-23 (1999).

b). H. Lavanant; Y. Hoppilliard and H.Virelizier, Reduction of copper(ii) complexes by electron capture in an electrospray ionization source. J. Am. Soc. Mass Spectrom. 9, 1217-1121 (1998).

31. a). C.L. Gatlin; F. Turecek and T. Vaisar, Gas-Phase Complexes of Amino Acids With $\mathrm{Cu}(\mathrm{II})$ and Diimine Ligands 1. Aliphatic and aromatic Amino Acids. J. Mass Spectrom. 30, 1605-1616 (1995).

b). C.L. Gatlin; F. Turecek and T. Vaisar, Gas-Phase Complexes of Amino Acids With $\mathrm{Cu}(\mathrm{II})$ and Diimine Ligands 2. Amino Acids with $\mathrm{O}, \mathrm{N}$ and S Functional Groups in the Side Chain. J. Mass Spectrom. 30, 1617-1627 (1995).

c). T. Vaisar; C.L. Gatlin and F. Turecek, Oxidation of Peptide-Copper Complexes by Alkali Metal Cations in the Gas Phase. J. Am. Chem. Soc. 118, 5314-5315 (1996).

d) T. Vaisar, C.L. Gatlin, R. D. Rao, J. L. Seymour, F. Turecek, Sequence information, distinction and quantitation of C-terminal leucine and isoleucine in ternary complexes of tripeptides with cu(II) and 2,2'-bipyridine. J. Mass Spectrom. 36, 306-316 (2001).

32. L. Boutreau, E. Léon, L. Rodriguez-Santiago, P. Toulhoat, O. Mó, J. Tortajada, GasPhase Reactivity of $\mathrm{Cu}^{+}$and $\mathrm{Ag}^{+}$with Glycerol: an Experimental and Theoretical Study. J. Phys. Chem. A 106, 10563-10577 (2002). 


\section{FIGURE CAPTIONS}

Figure 1 : Positive ion electrospray mass spectra of an aqueous $\mathrm{AgNO}_{3} / \mathrm{D}-\mathrm{Glucose}(\mathrm{a})$, $\mathrm{AgNO}_{3} / \mathrm{D}$-Galactose (b) and $\mathrm{AgNO}_{3} / \mathrm{D}$-Fructose (c)recorded at a cone voltage of $35 \mathrm{~V}$.

Figure 2 : Low-energy CID mass spectra of (a) [Ag(glucose) $]^{+}$, (b) [Ag(galactose) $]^{+}$and (c) $[\mathrm{Ag}(\text { fructose })]^{+}$recorded at a cone voltage of $35 \mathrm{~V}$ and a collision energy of $15 \mathrm{eV}$.

Figure 3: Low-energy CID mass spectra of (a) $[\mathrm{Ag}(\alpha \text {-O-methyl-glucose })]^{+}$ $\left(\boldsymbol{\alpha}-\mathbf{4} \mathbf{A g}^{+}\right)$and (b) $[\mathrm{Ag}(\beta-O-m e t h y l \text { glucose })]^{+}\left(\beta-5 \mathbf{A g}^{+}\right)$recorded at a cone voltage of $35 \mathrm{~V}$ and a collision energy of $20 \mathrm{eV}$.

Figure 4: Positive ion electrospray mass spectra of an aqueous $\mathrm{CuCl}_{2} / \mathrm{D}$-Glucose (a), $\mathrm{CuCl}_{2} / \mathrm{D}$-Galactose (b) and $\mathrm{CuCl}_{2} / \mathrm{D}$-Fructose (c) recorded at a cone voltage of $50 \mathrm{~V}$.

Figure 5 : Low-energy CID mass spectra of (a) $[\mathrm{Cu} \text { (glucose) }]^{+}$, (b) $[\mathrm{Cu} \text { (galactose) }]^{+}$and (c) $[\mathrm{Cu}(\text { fructose })]^{+}$recorded at a cone voltage of $50 \mathrm{~V}$ and a collision energy of $20 \mathrm{eV}$.

Figure 6 : Low-energy CID mass spectra of $\left[{ }^{63} \mathrm{Cu}(\mathrm{O}-\text { methyl- } \alpha \text {-D-glucose })\right]^{+}\left(\boldsymbol{\alpha}-\mathbf{4 C} \mathbf{u}^{+}\right)$ recorded at a cone voltage of $35 \mathrm{~V}$ and a collision energy of $15 \mathrm{eV}$.

Figure 7 : Low-energy CID mass spectra of (a) [Cu(II)(O-methyl- $\alpha$-D-glucose) $-\mathrm{H}]^{+}$

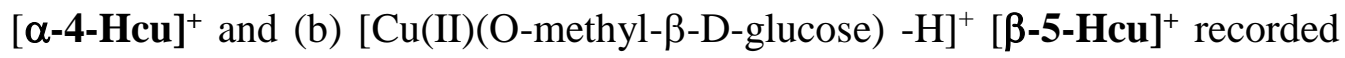
at a cone voltage of $35 \mathrm{~V}$ and a collision energy of $20 \mathrm{eV}$.

Figure 8 : Geometries of neutral pyranosic forms of $\alpha$-D-O-Methyl Glucoside $(\alpha-4)$ and $\beta$-D-O-Methyl Glucoside ( $\beta$-5). 
Figure 9 : Geometries of selected [Cu-D-O-Methyl Glucoside $]^{+}$anomers $(\boldsymbol{\alpha}-\mathbf{4 C u})^{+}$and $(\boldsymbol{\beta}-\mathbf{5 C u})^{+}$complexes.

Figure 10 : Geometries of selected [Ag-D-O-Methyl Glucoside $]^{+}$anomers, $(\boldsymbol{\alpha}-\mathbf{4 A g})^{+}$and $\left(\boldsymbol{\beta}\right.$-5Ag) ${ }^{+}$complexes. 
(a)
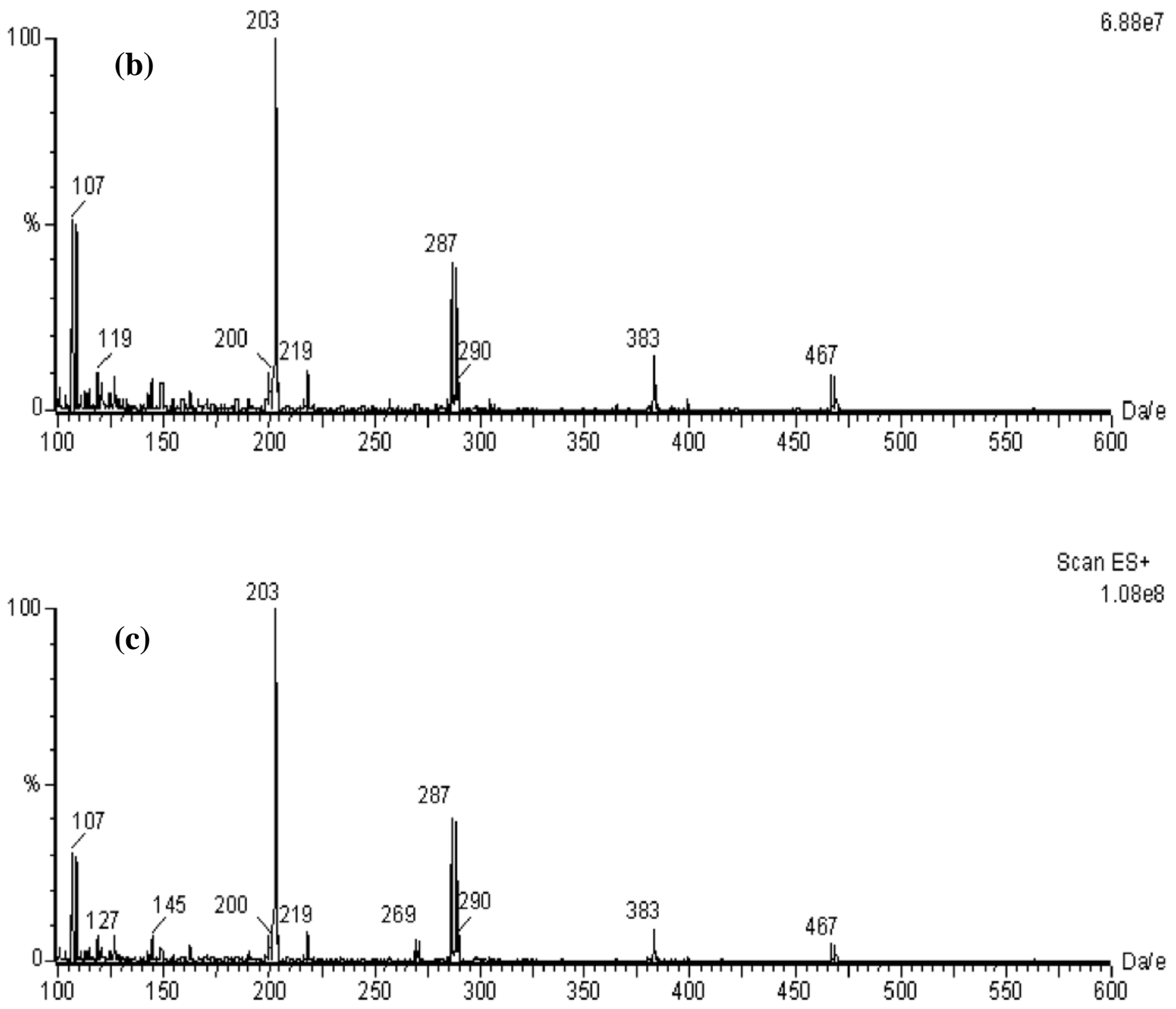

Figure 1 
(1)

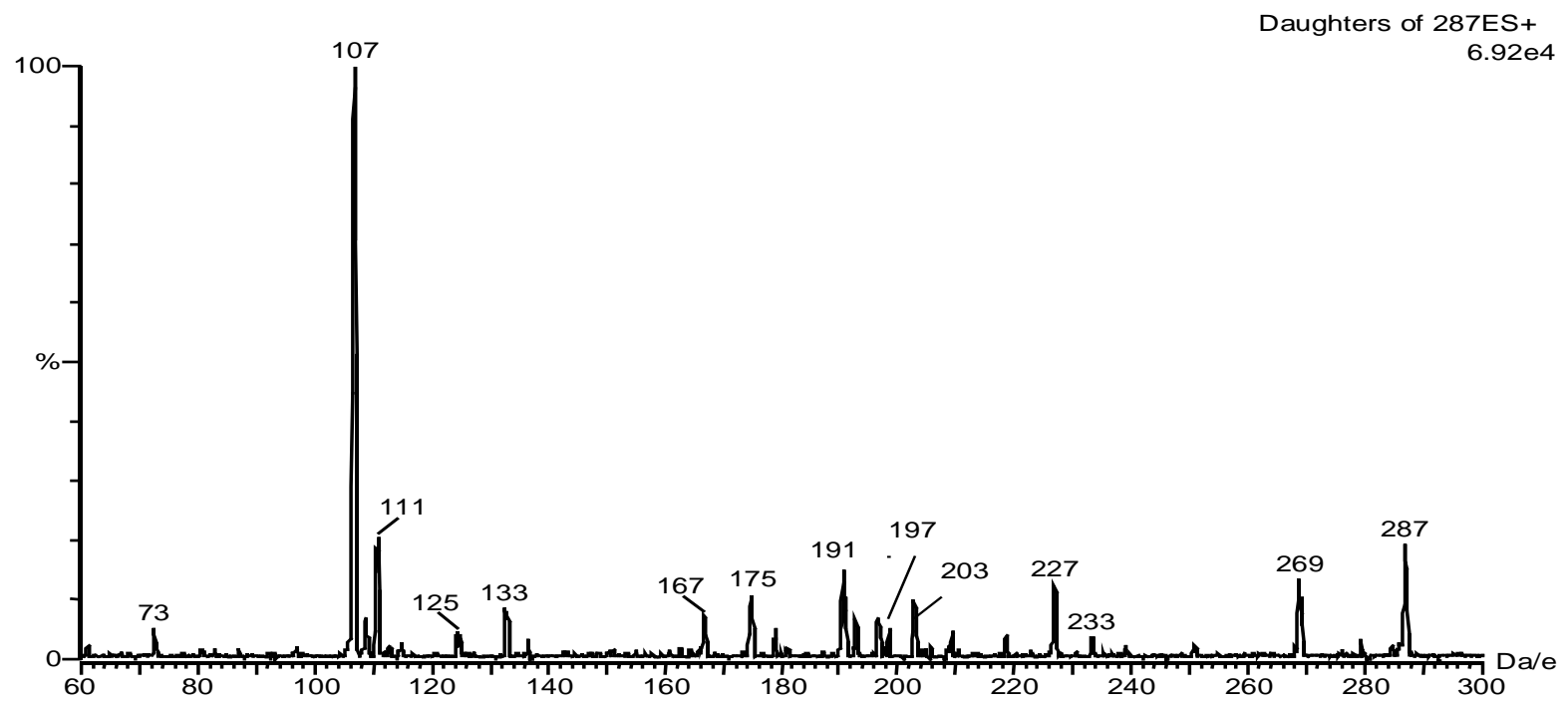

(2)

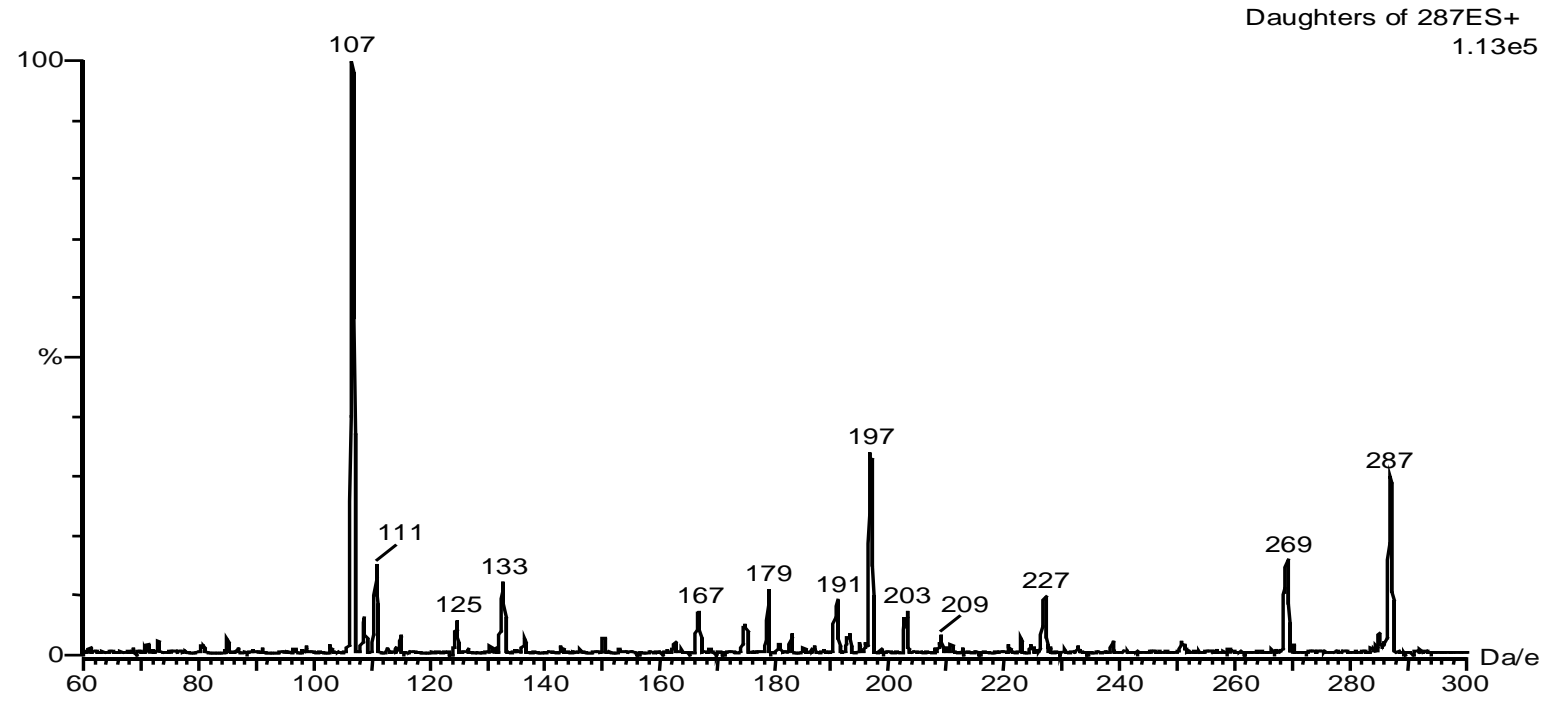

(3)

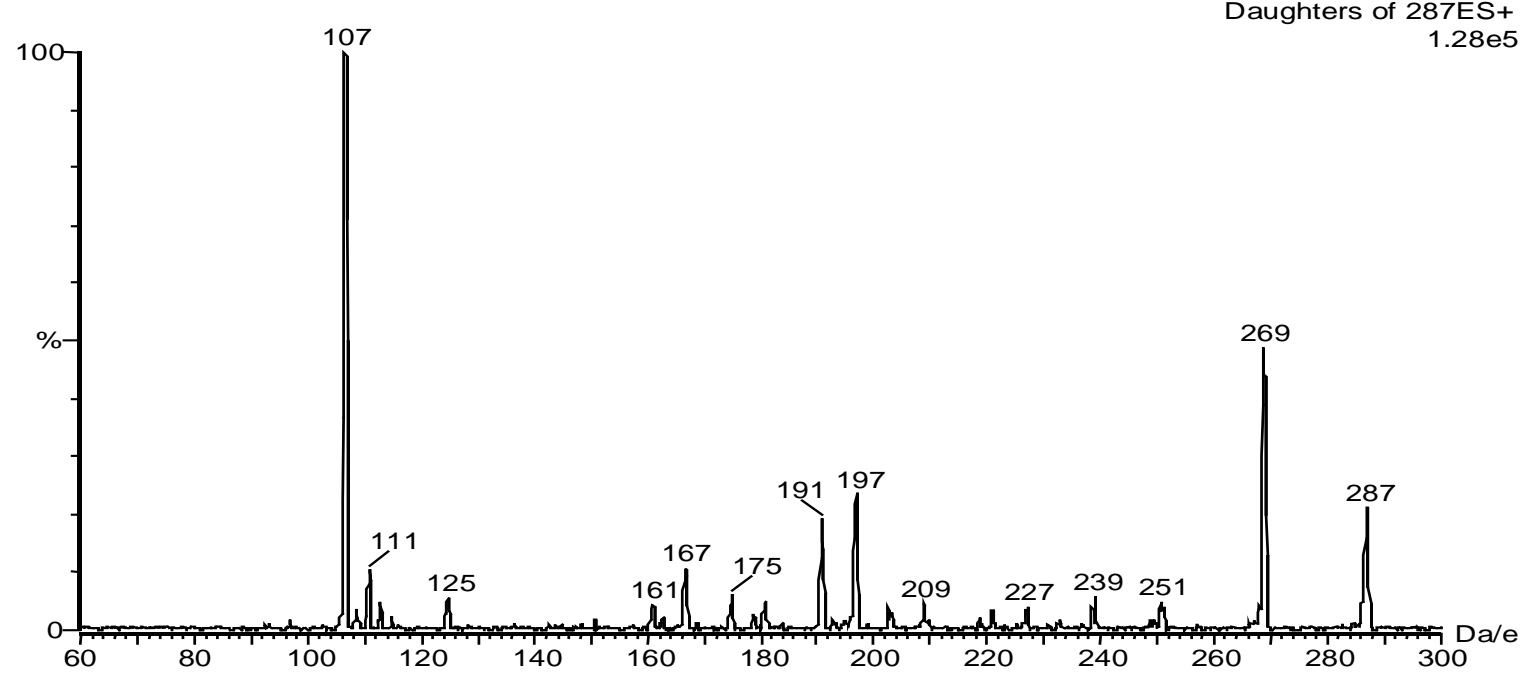

Figure 2 
(1)

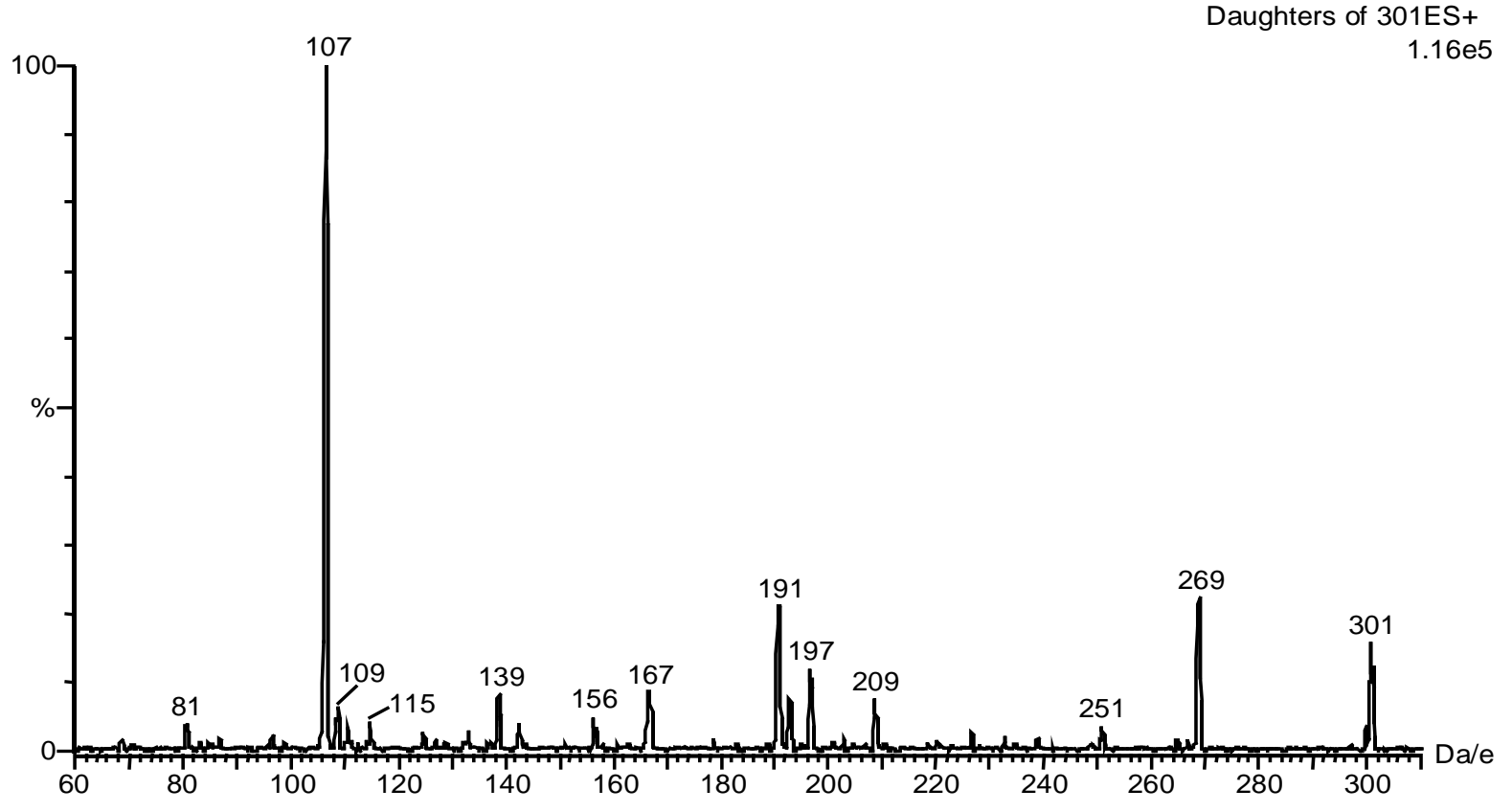

(2)

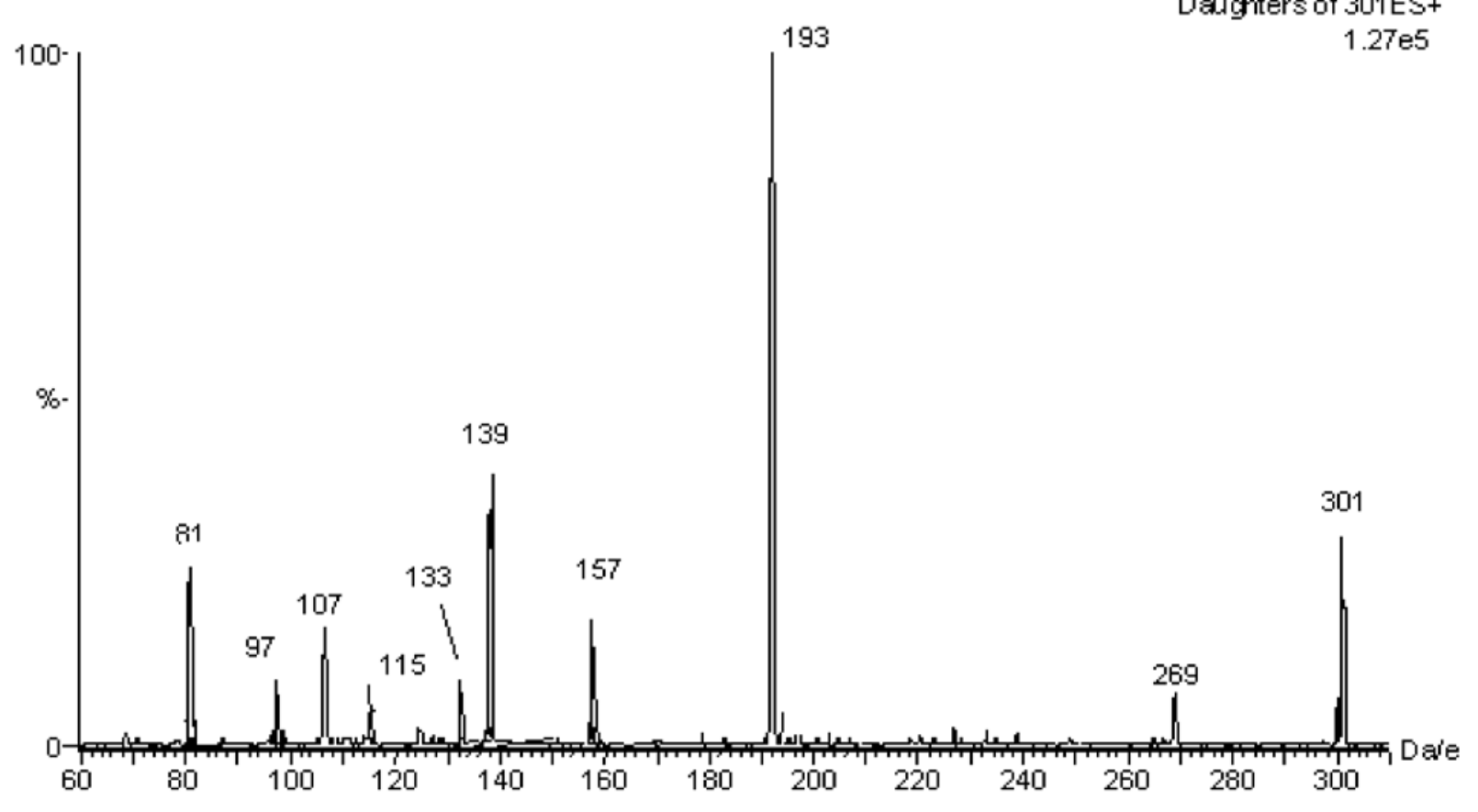



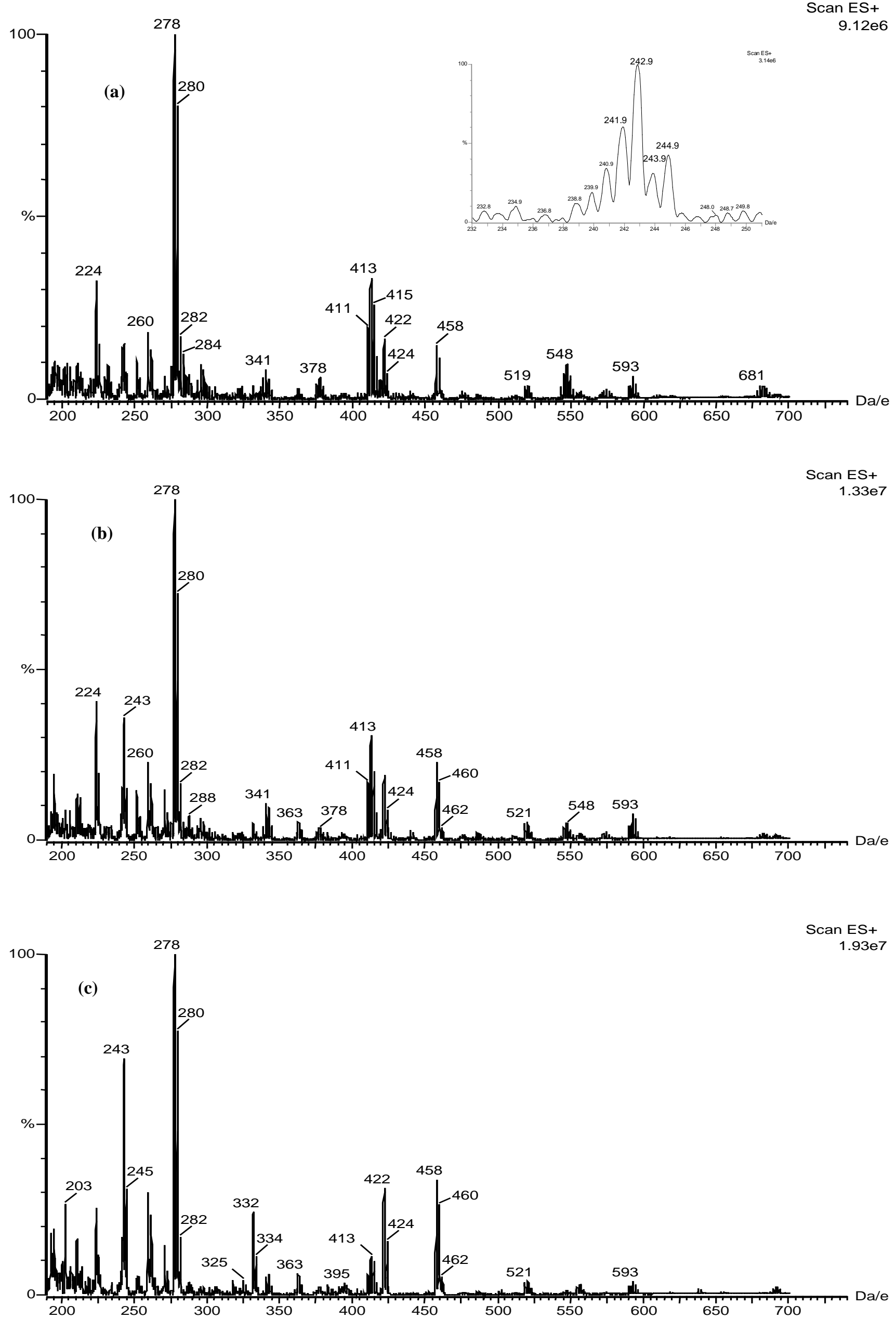

Figure 4 

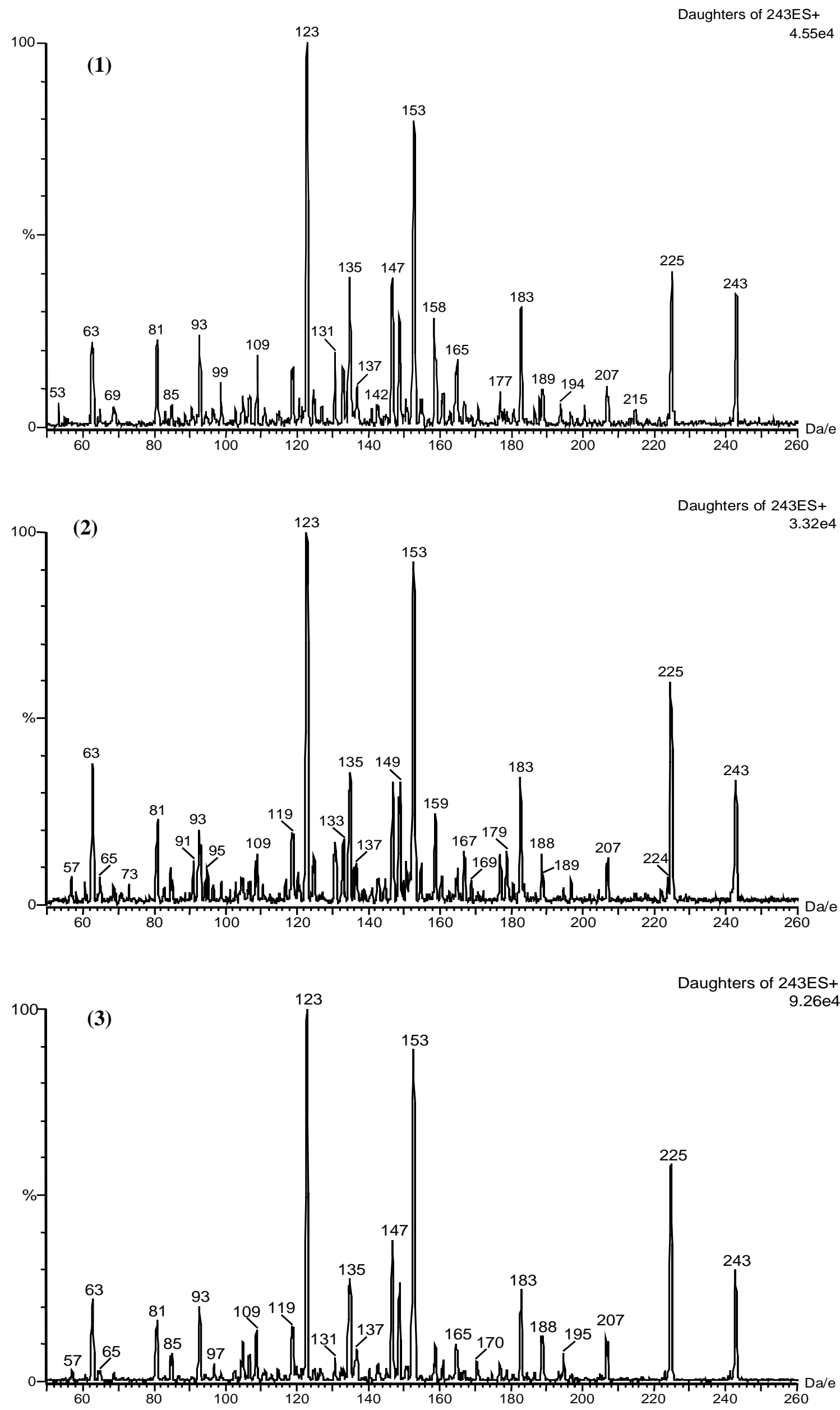

Figure 5 


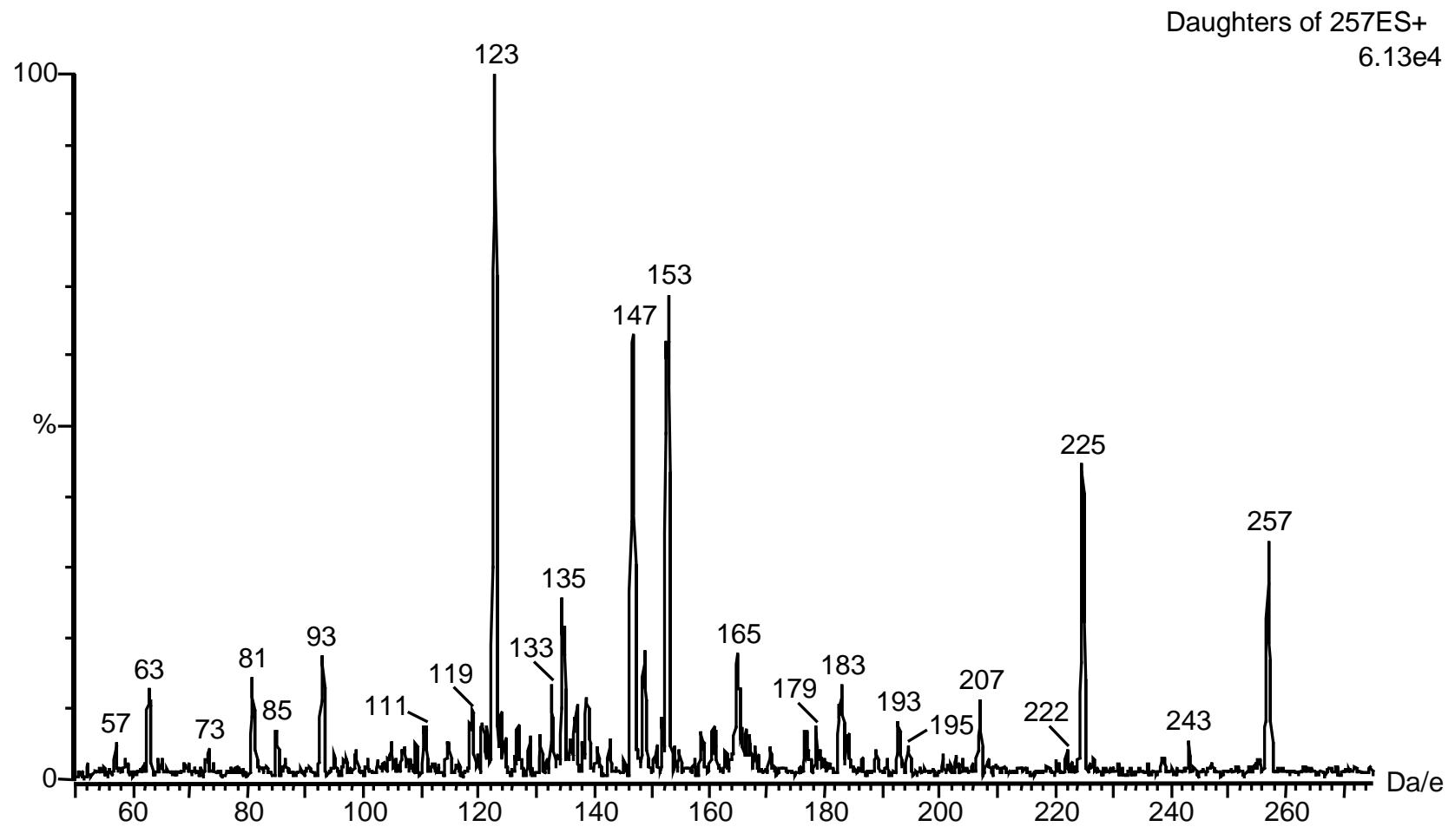

Figure 6 

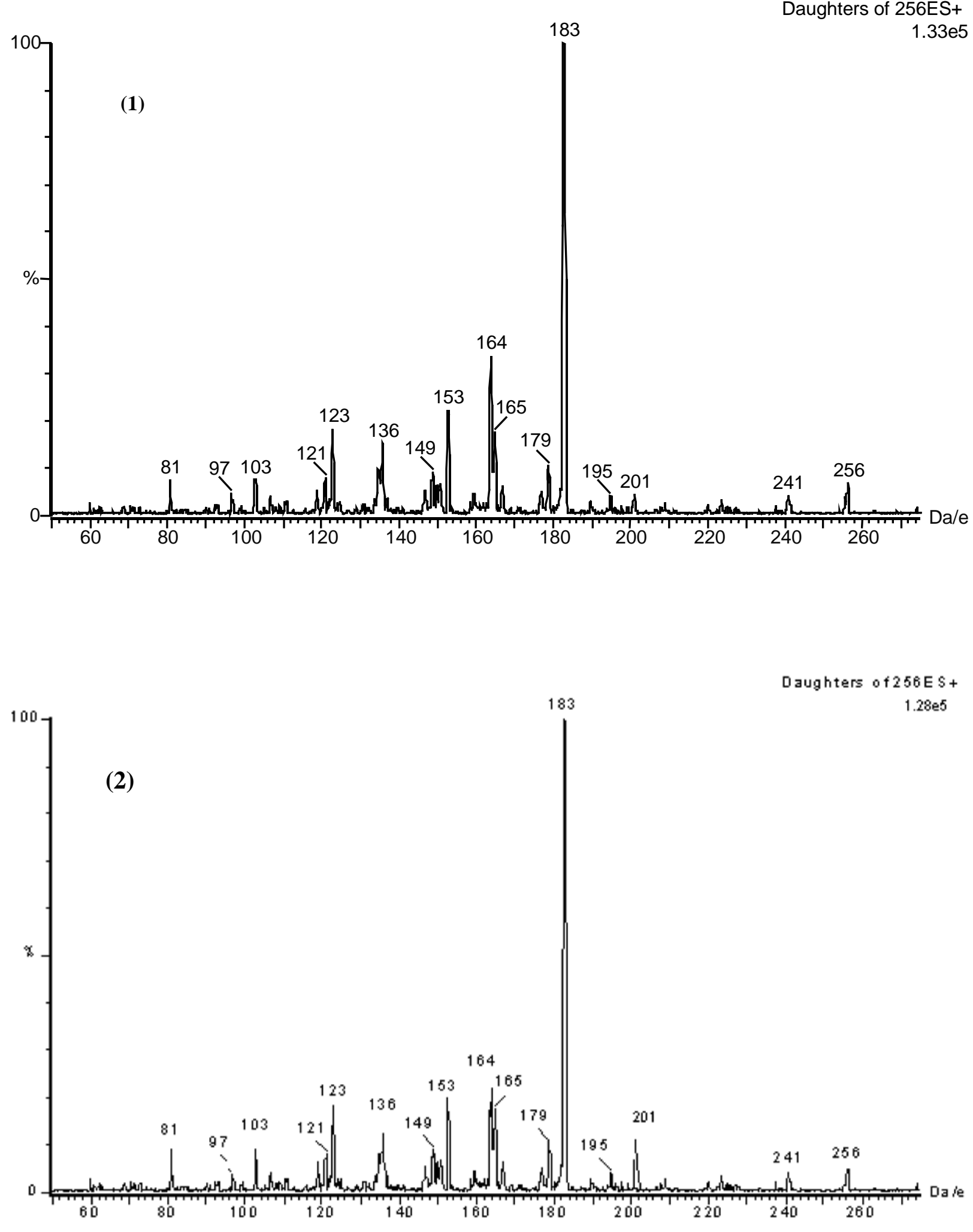

Figure 7 

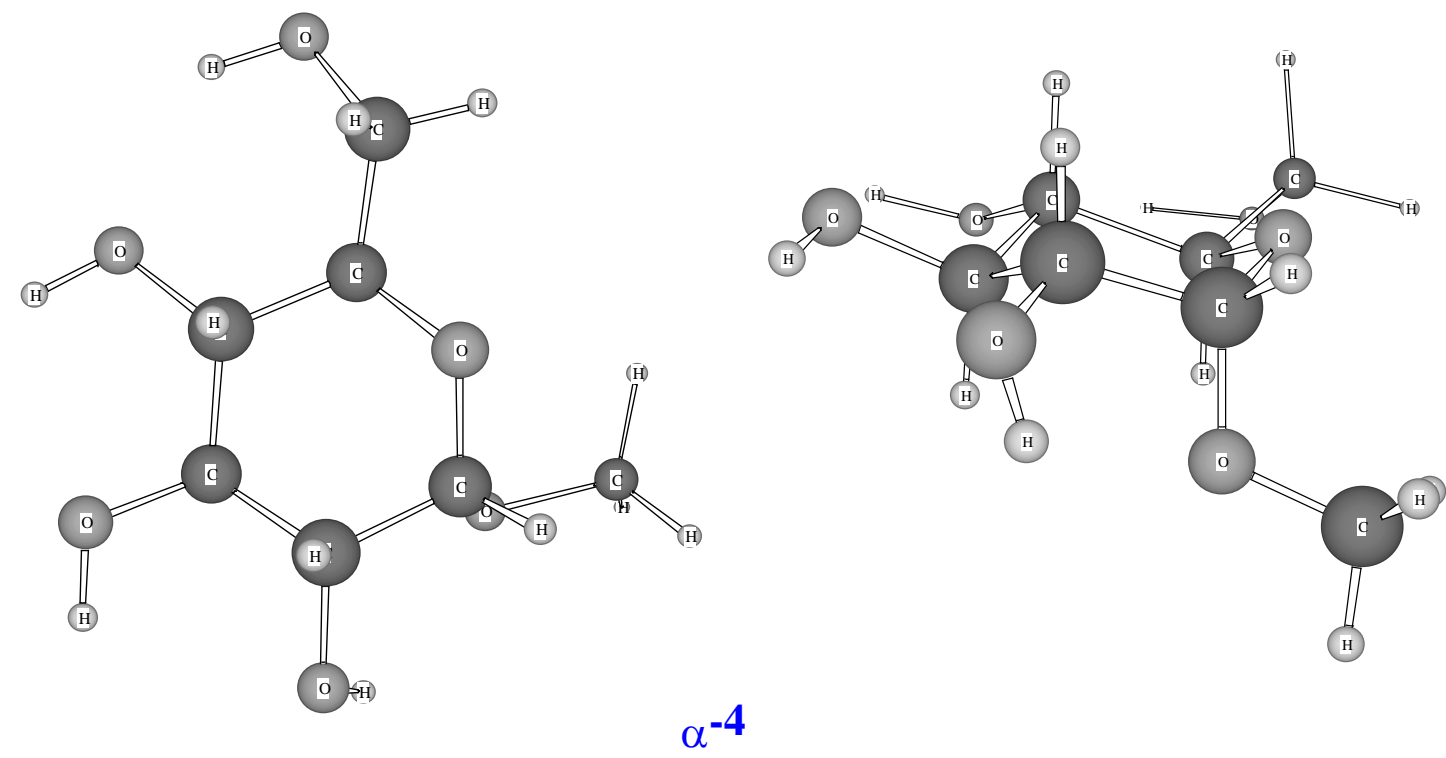

$\alpha^{-4}$
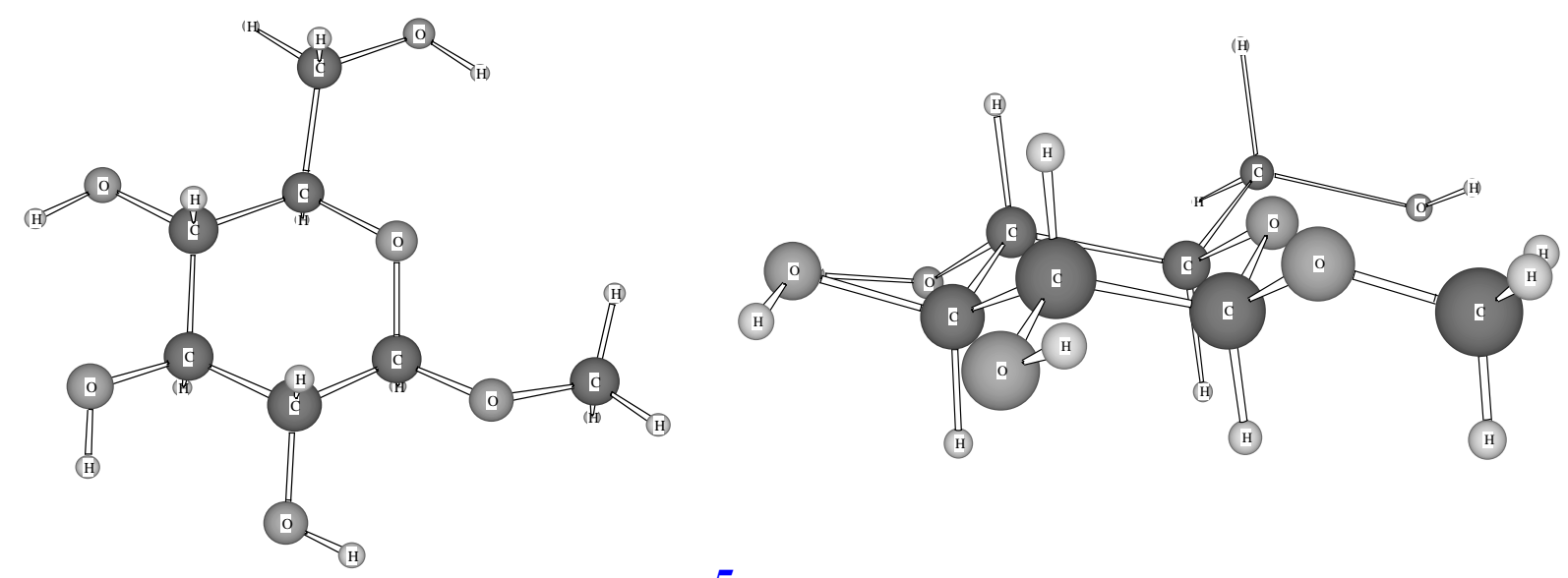

$\beta^{-5}$

Figure 8 

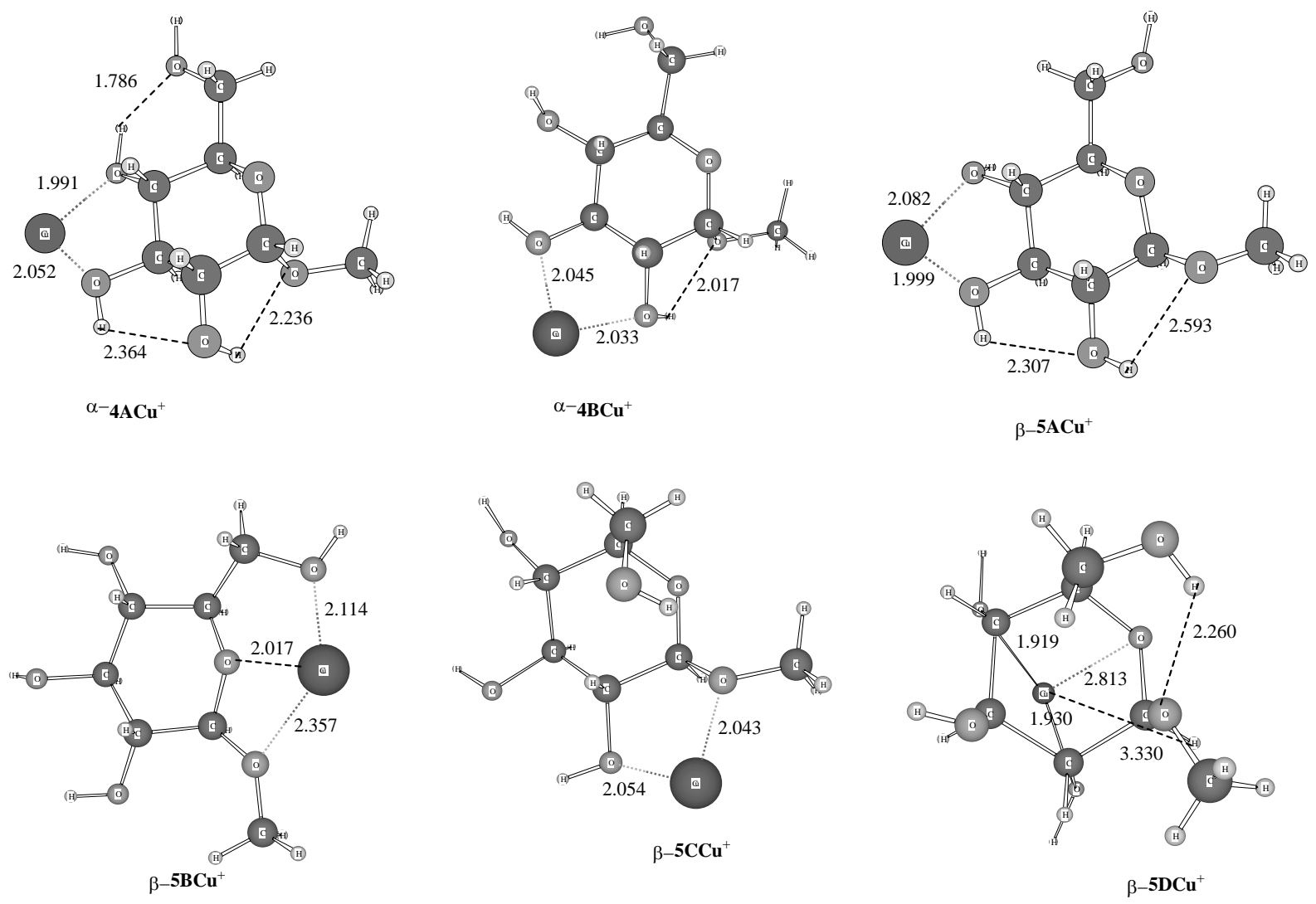

Figure 9 

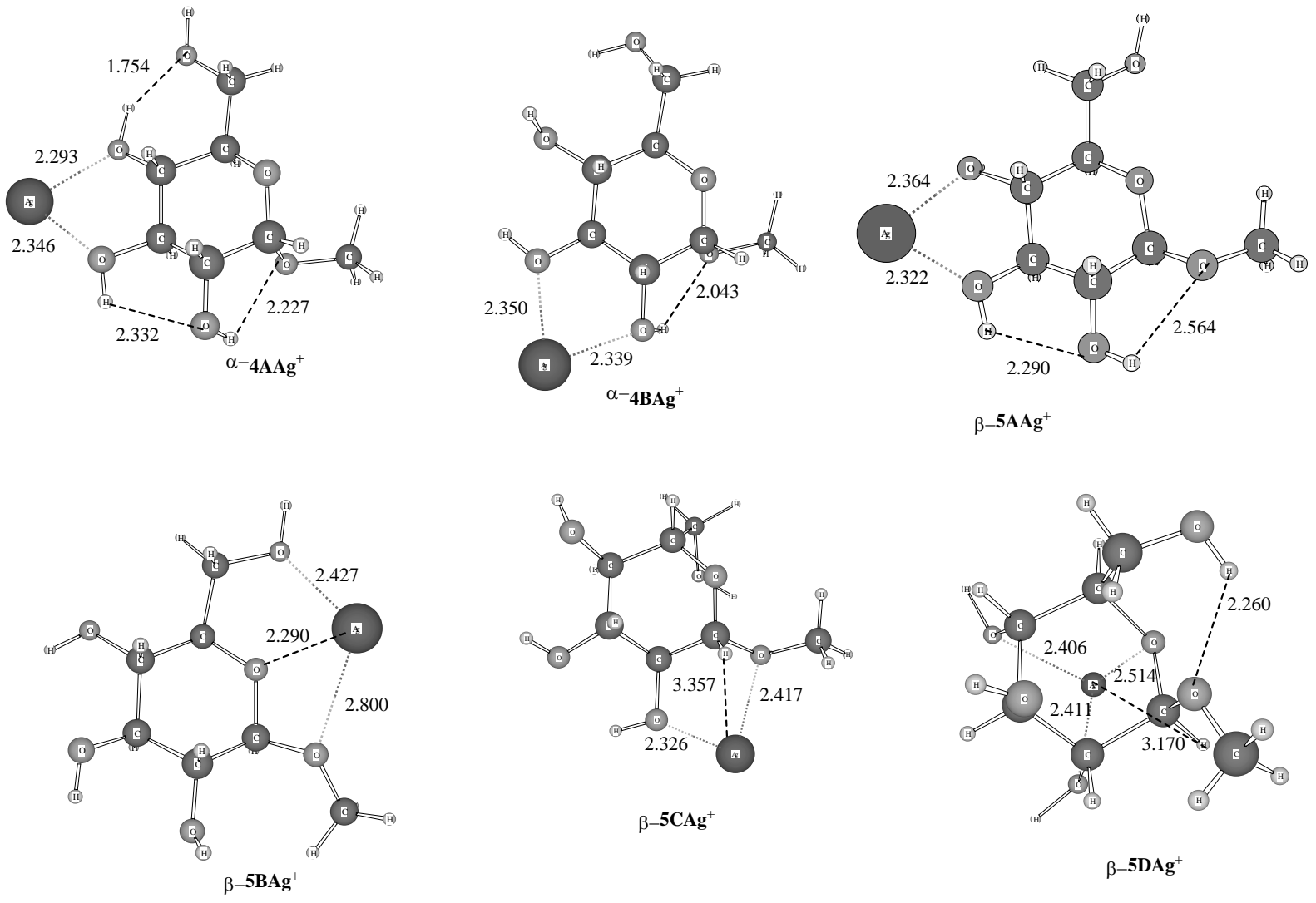

Figure 10 


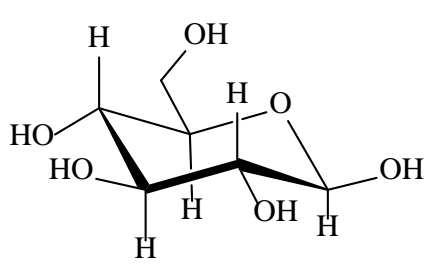

1

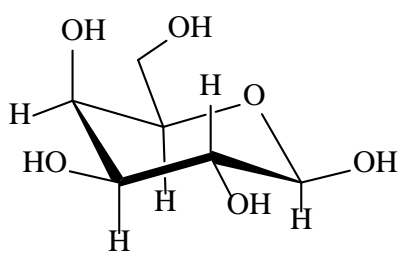

2

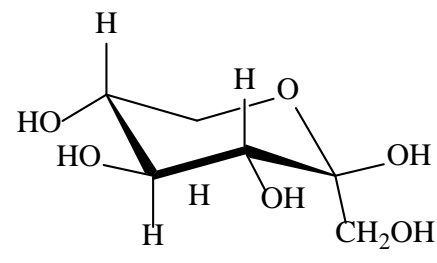

3

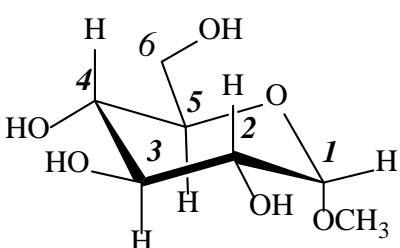

4

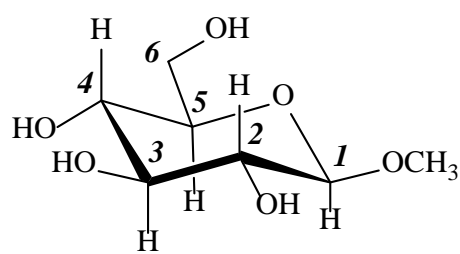

5

Scheme1

Scheme 1 
m/z 225

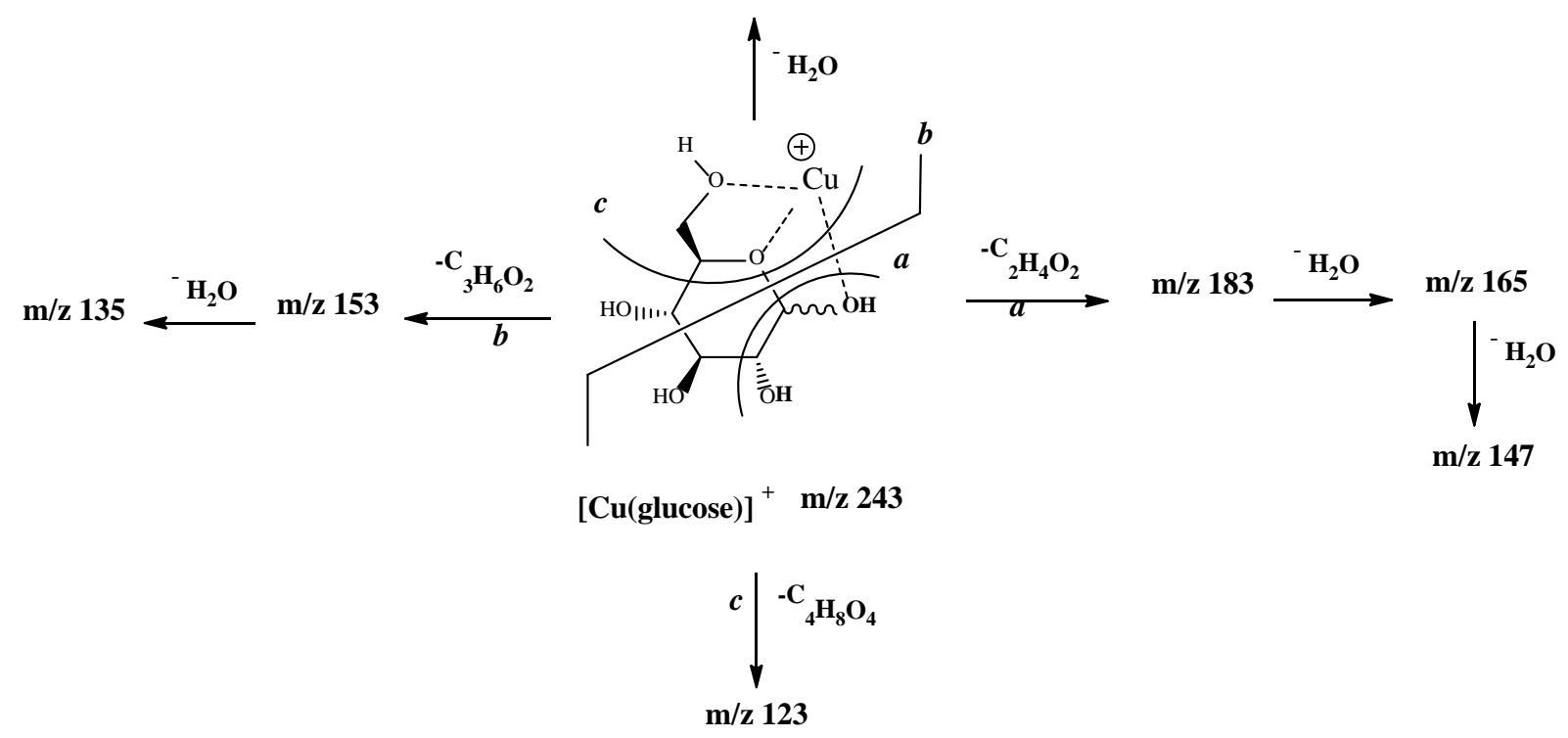

Scheme 2

\section{Scheme 2}




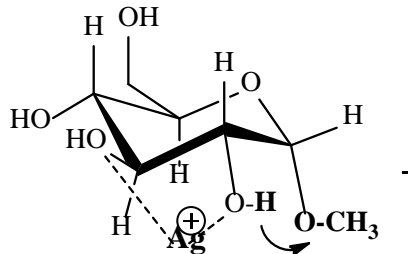

$\alpha^{-4 B A g}+$

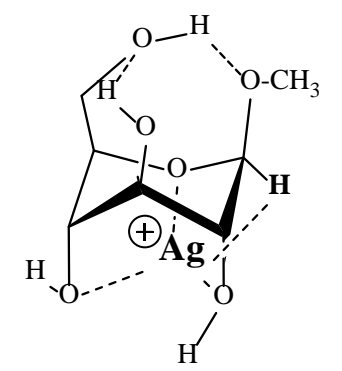

$\beta-5$ DAg $^{+}$
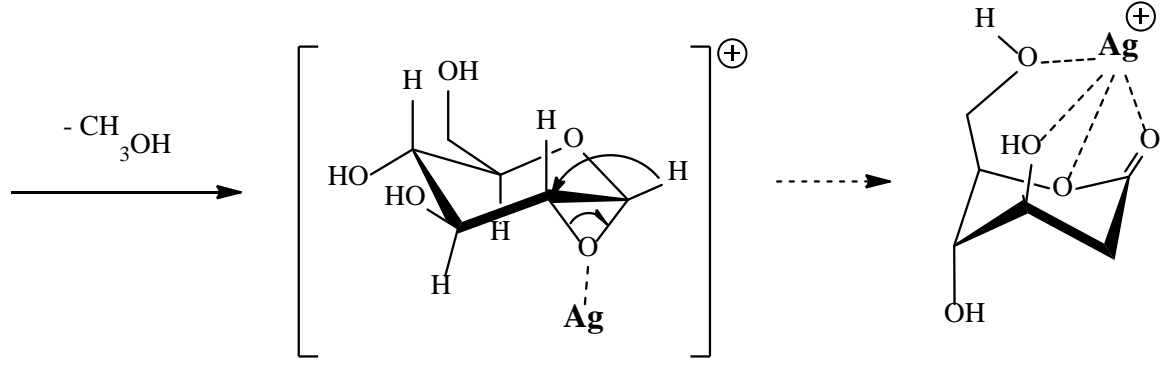

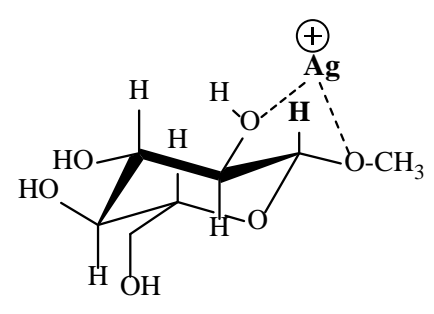

$\beta-5 \mathrm{CAg}^{+}$

Scheme 3 

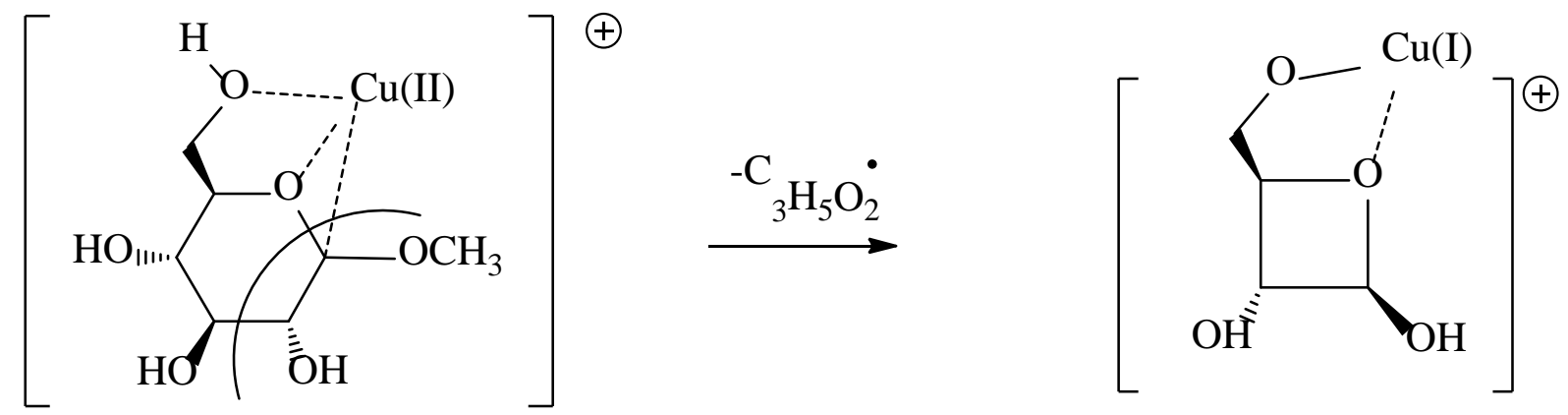

Scheme 4 


\begin{tabular}{|c|c|c|c|c|c|c|c|c|c|}
\hline \multirow[t]{2}{*}{ 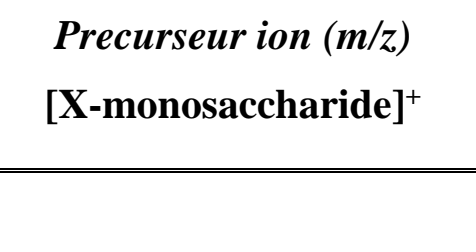 } & \multicolumn{9}{|c|}{$\begin{array}{c}\text { Product ion }(\mathrm{m} / \mathrm{z}) \\
\text { Neutral losses }\end{array}$} \\
\hline & $-\mathrm{H}_{2} \mathrm{O}$ & $-2 \mathrm{H}_{2} \mathrm{O}$ & $-\mathrm{C}_{2} \mathrm{H}_{4} \mathrm{O}_{2}$ & $-\mathrm{C}_{2} \mathrm{H}_{4} \mathrm{O}_{2} /-\mathrm{H}_{2} \mathrm{O}$ & $-\mathrm{C}_{3} \mathrm{H}_{6} \mathrm{O}_{3}$ & $-\mathrm{C}_{2} \mathrm{H}_{4} \mathrm{O}_{2} /-2 \mathrm{H}_{2} \mathrm{O}$ & $-\mathrm{C}_{3} \mathrm{H}_{6} \mathrm{O}_{3} /-\mathrm{H}_{2} \mathrm{O}$ & $-\mathrm{C}_{4} \mathrm{H}_{8} \mathrm{O}_{2}$ & $-\mathrm{C}_{6} \mathrm{H}_{12} \mathrm{O}_{6}$ \\
\hline 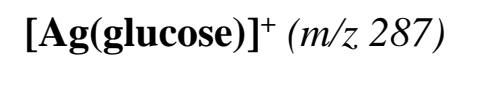 & $\begin{array}{c}m / z 269 \\
\mathbf{1 3}\end{array}$ & $\begin{array}{c}m / z 251 \\
\mathbf{2}\end{array}$ & $\begin{array}{c}m / z 227 \\
13\end{array}$ & $\begin{array}{c}m / z 209 \\
2\end{array}$ & $\begin{array}{c}m / z 197 \\
7\end{array}$ & $\begin{array}{c}m / z 191 \\
\mathbf{1 5}\end{array}$ & $\begin{array}{c}m / z 179 \\
2\end{array}$ & $\begin{array}{c}m / z 167 \\
\mathbf{1 2}\end{array}$ & $\begin{array}{c}\mathrm{m} / \mathrm{z} 107 \\
\mathbf{1 0 0}\end{array}$ \\
\hline [Ag(galactose)] $^{+}(\mathrm{m} / \mathrm{z} 287)$ & $\begin{array}{c}m / z 269 \\
30\end{array}$ & $\begin{array}{c}m / z 251 \\
\mathbf{2}\end{array}$ & $\begin{array}{c}m / z 227 \\
\mathbf{8}\end{array}$ & $\begin{array}{c}m / z 209 \\
2\end{array}$ & $\begin{array}{c}m / z 197 \\
35\end{array}$ & $\begin{array}{c}m / z 191 \\
\mathbf{8}\end{array}$ & $\begin{array}{c}m / z 179 \\
\mathbf{1 1}\end{array}$ & $\begin{array}{c}m / z 167 \\
\mathbf{6}\end{array}$ & $\begin{array}{c}\mathrm{m} / \mathrm{z} 107 \\
\mathbf{1 0 0}\end{array}$ \\
\hline$[\text { Ag(fructose) }]^{+}(m / z$ 287) & $\begin{array}{c}m / z 269 \\
\mathbf{5 0}\end{array}$ & $\begin{array}{c}m / z 251 \\
\mathbf{3}\end{array}$ & $\begin{array}{c}m / z 227 \\
\mathbf{3}\end{array}$ & $\begin{array}{c}m / z 209 \\
2\end{array}$ & $\begin{array}{c}m / z 197 \\
\mathbf{2 4}\end{array}$ & $\begin{array}{c}m / z 191 \\
\mathbf{2 0}\end{array}$ & $\begin{array}{c}m / z 179 \\
2\end{array}$ & $\begin{array}{c}m / z 167 \\
\mathbf{1 0}\end{array}$ & $\begin{array}{c}\mathrm{m} / \mathrm{z} 107 \\
\mathbf{1 0 0}\end{array}$ \\
\hline$[\mathbf{C u}(\text { glucose })]^{+}(\mathrm{m} / \mathrm{z} 243)$ & $\begin{array}{c}m / z 225 \\
45\end{array}$ & $\begin{array}{c}m / z 207 \\
\mathbf{1 0}\end{array}$ & $\begin{array}{c}m / z 183 \\
\mathbf{3 0}\end{array}$ & $\begin{array}{c}m / z 165 \\
\mathbf{1 7}\end{array}$ & $\begin{array}{c}m / z 153 \\
\mathbf{8 0}\end{array}$ & $\begin{array}{c}m / z 147 \\
\mathbf{3 0}\end{array}$ & $\begin{array}{c}m / z 135 \\
39\end{array}$ & $\begin{array}{c}\mathrm{m} / \mathrm{z} 123 \\
\mathbf{1 0 0}\end{array}$ & $\begin{array}{c}m / z 63 \\
\mathbf{2 1}\end{array}$ \\
\hline [Cu(galactose)] $^{+}(\mathrm{m} / \mathrm{z}$ 243) & $\begin{array}{c}\mathrm{m} / \mathrm{z} 225 \\
\mathbf{5 7}\end{array}$ & $\begin{array}{c}m / z 207 \\
\mathbf{1 2}\end{array}$ & $\begin{array}{c}m / z 183 \\
32\end{array}$ & $\begin{array}{c}m / z 165 \\
\mathbf{9}\end{array}$ & $\begin{array}{c}m / z 153 \\
\mathbf{9 0}\end{array}$ & $\begin{array}{c}\mathrm{m} / \mathrm{z} 147 \\
32\end{array}$ & $\begin{array}{c}m / z 135 \\
\mathbf{3 6}\end{array}$ & $\begin{array}{c}\mathrm{m} / \mathrm{z} 123 \\
\mathbf{1 0 0}\end{array}$ & $\begin{array}{c}m / z 63 \\
35\end{array}$ \\
\hline$[\mathbf{C u}(\text { fructose })]^{+}$(m/z 243) & $\begin{array}{c}m / z 225 \\
\mathbf{5 8}\end{array}$ & $\begin{array}{c}m / z 207 \\
\mathbf{1 0}\end{array}$ & $\begin{array}{c}m / z 183 \\
\mathbf{2 4}\end{array}$ & $\begin{array}{c}m / z \\
9\end{array}$ & $\begin{array}{c}m / z 153 \\
\mathbf{8 5}\end{array}$ & $\begin{array}{c}\mathrm{m} / \mathrm{z} 147 \\
\mathbf{3 0}\end{array}$ & $\begin{array}{c}m / z 135 \\
\mathbf{2 8}\end{array}$ & $\begin{array}{c}\mathrm{m} / \mathrm{z} 123 \\
\mathbf{1 0 0}\end{array}$ & $\begin{array}{c}m / z 63 \\
25\end{array}$ \\
\hline
\end{tabular}

Table 1 : Principal fragmentations and abundance ions obtained from MS/MS spectra recorded at a skimmer voltage of 35V and a collision energy of $15 \mathrm{eV}$ for silver complexes, and $50 \mathrm{~V}$ and $20 \mathrm{eV}$ for copper complexes, respectively. 


\begin{tabular}{|c|c|c|c|c|c|c|}
\hline Structure & $\mathrm{E}^{\mathrm{a}}$ (hartree) & $\mathrm{ZPE}^{\mathrm{a}}$ ( hartree) & $\Delta \mathbf{E}^{\mathrm{a}, \mathrm{b}}(\mathrm{kJ} / \mathrm{mol})$ & $\mathrm{E}^{\mathrm{c}}$ (hartree) & $\Delta \mathrm{E}^{\mathrm{c}, \mathrm{d}}(\mathrm{kJ} / \mathrm{mol})$ & $\mathrm{B}_{\mathrm{X}}^{+}(\mathrm{kJ} / \mathrm{mol})^{\mathrm{e}, \mathrm{I}}$ \\
\hline$\alpha-4$ & -726.537549 & 0.225915 & 0.0 & -726.731813 & 0.0 & - \\
\hline$\beta-5$ & -726.535768 & 0.224924 & 2.1 & -726.728754 & 5.4 & - \\
\hline$\alpha-4 \mathrm{ACu}^{+}$ & -2366.917429 & 0.227462 & 0.0 & -2366.962425 & 0.0 & 334 \\
\hline$\beta-5 \mathrm{ACu}^{+}$ & -2366.896541 & 0.225866 & 50.6 & -2366.943476 & 45.6 & 288 \\
\hline$\alpha-4 \mathrm{BCu}^{+}$ & -2366.902567 & 0.227377 & 38.9 & -2366.94875 & 35.7 & 298 \\
\hline$\beta-5 B C \mathbf{u}^{+}$ & -2366.906281 & 0.225248 & 23.5 & -2366.953303 & 18.1 & 321 \\
\hline$\beta-5 C C u^{+}$ & -2366.893875 & 0.226641 & 59.7 & -2366.940911 & 54.3 & 285 \\
\hline$\beta-5 D C u^{+}$ & -2366.898164 & 0.227136 & 49.7 & -2366.946653 & 40.6 & 293 \\
\hline$\alpha-4 A A g$ & -872.058613 & 0.228090 & 0.0 & -872.298837 & 0.0 & 239 \\
\hline$\beta-5 A A g$ & -872.036777 & 0.226258 & 52.5 & -872.280001 & 44.6 & 194 \\
\hline$\alpha-4 B A^{+}$ & -872.0429264 & 0.227515 & 39.7 & -872.284642 & 35.8 & 203 \\
\hline$\beta-5 B A^{+}$ & -872.045690 & 0.22649 & 29.7 & -872.287696 & 25.0 & 219 \\
\hline$\beta-5 \mathrm{CAg}^{+}$ & -872.032124 & 0.227476 & 67.9 & -872.273997 & 63.6 & 181 \\
\hline$\beta-5 D A g^{+}$ & -872.034135 & 0.227086 & 61.6 & -872.274664 & 60.8 & 184 \\
\hline
\end{tabular}

Table 2 : Total $(\mathrm{E})$, relative energies $(\Delta \mathrm{E})$ and binding energies $\left(\mathrm{Bx}^{+}\right)$for neutral and cationized copper and silver - $\alpha$ - and $\beta$-O-methyl D-glucoside anomers ( $\alpha-4$ and $\beta$-5) structures.

a) Calculated with Basis1. ${ }^{\text {b) }}$ Values evaluated with Basis1 including ZPE corrections. ${ }^{c)}$ Calculated with Basis2.

d) Values evaluated with Basis2 including ZPE corrections. ${ }^{\mathrm{e})} \mathrm{B}_{\mathrm{X}^{+}}^{+} \alpha-4 \mathrm{ACu}+{ }^{+}=\left(\mathrm{E}_{\mathrm{Cu}^{+}}+\mathrm{E}_{\alpha-4}\right)-\mathrm{E}_{\alpha-4 \mathrm{ACu}^{+}}$.

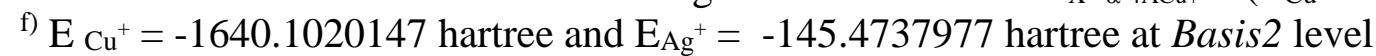

